\title{
Recent Developments Studies on Wood Protection Research in Academia: A Review
}

\author{
Laya Khademibamit and Gabrielly S. Bobadilha*t \\ Department of Sustainable Bioproducts, Mississippi State University, Starkville, MS, United States
}

The wood preservation industry has taken large leaps to develop and produce chemicals that protect wood from microorganisms and weathering degradation with no or low environmental impact. These improvements occurred after concerns of federal and public agencies about the release of toxic components into atmosphere, soil, and water. These days, reduction in use of non-renewable resources is a crucial concern. Wood and wood-based products are generally low in $\mathrm{CO}_{2}$ emissions and

\section{OPEN ACCESS}

Edited by:

Grant Terral Kirker,

Forest Products Laboratory, United States Forest Service (USDA),

United States

Reviewed by:

Tahamina Khanam

University of Eastern Finland, Finland Antti Haapala,

University of Eastern Finland, Finland

${ }^{*}$ Correspondence:

Gabrielly S. Bobadilha

gd450@msstate.edu

tThese authors have contributed equally to this work and share first authorship

Specialty section: This article was submitted to

Forest Management,

a section of the journal Frontiers in Forests and Global

Change

Received: 11 October 2021

Accepted: 08 February 2022

Published: 07 March 2022

Citation:

Khademibami $L$ and

Bobadilha GS (2022) Recent Developments Studies on Wood Protection Research in Academia:

A Review.

Front. For. Glob. Change 5:793177.

doi: 10.3389/ffgc.2022.793177 can be gained from sustainable forest resources. Therefore, they can play a significant role as renewable resources. In comparison to other building materials, wood has numerous advantages, such as suitable thermal insulation, high strength to weight ratio, easy machinability, and attractive esthetics. Wood as a valuable building and industrial material requires to be protected due to its biodegradable properties especially when it is submitted to harsh conditions. Wood durability can be improved through wood protection which include wood preservatives and modification systems. Wood protection should be safe to use, efficient, cost-effective, permanent, and should not corrode metal or degrade wood components. Numerous reviews of wood protection can be found in the scientific literatures, but until now a review of a combination of wood preservation and wood modification has not been studied. It should be considered that the latest research projects in wood protection in academia not always reflect the most current developments in the industry due to exclusive rights. The findings reported in academia contribute to the safe use of preservatives, advancement of wood modification techniques, as well as recycle and disposal of treated material. Therefore, in this study, the most current research and advancements promoted in the wood protection in academia are discussed which including an overall summary of the recent developments on wood preservatives, different types of preservatives, natural preservative compounds, and modification technologies in academia.

Keywords: wood preservation, wood protection, wood modification, preservatives, environmental impacts, durability

Abbreviations: ACA, Ammoniacal copper arsenate; ACQ, alkaline copper quat; ACZA, ammoniacal copper zinc arsenate; APB, ammonium pentaborate; ARS, Agricultural Research Service; ATFB, ammonium tetrafluoroborate; AWPA, American Wood Protection Association; BA, boric acid; BMPS, best management practices; CA, copper azole; CCA, chromated copper arsenate; CCAP, counter-current attrition process; $\mathrm{CCB}$, Chromated copper borate, CHTM, hydro-thermomechanical wood modification; CM, chemical modification; CuN, copper naphthenate; DCOI, 5-dichloro-2-N-Octyl -4-Isothiazolin-3-One; IPBC, 3-iodo-2-propynyl-butylcarbamate; LG, Liquid glass; MOR, Moduli of rupture; PAC, polycyclic aromatic compounds; PAH'S, polycyclic aromatic hydrocarbons; PCP, pentachlorophenol; PFOTS, perfluorooctyltriethoxysilane (PFOTS); $\mathrm{TiO}_{2}$, titanium dioxide; TM, thermal modification; TMM, thermo-mechanical modification; U.S. EPA, United States Environmental Protection Agency; USDA, U.S. Department of Agriculture; UV, ultraviolet; ZnB, zinc borate. 


\section{INTRODUCTION}

Wood and wood products are present in different forms in building construction sector namely beams, cabinets, ceiling, flooring, and interior paneling. When wood and wood products are exposed to abiotic or biotic agents such water, heat, microorganisms, ultra-violet (UV) rays, and corrosive chemicals, they tend to deteriorate which may ultimately result in lack of safety for building occupants and economic losses. The service life of wooden products mainly depends on wood natural durability, design, and protection system. If wood is properly processed, it can last for a long time which can be demonstrated on historic buildings, utility and artistic objects, musical instruments, and other wood products.

In wood protection there are mainly two methods to preserve wood: wood preservation (chemical protection) and wood modification (modifying protection). While chemical protection is performed with preservatives, modification is done by activation of chemical components present in wood cell walls using high temperatures. In one hand, in wood preservation, traditional wood preservatives and methods employ chemicals that are considered toxic and can adversely affect human health and environment. Based on the impact of chemicals to the environment and human health, preservative restrictions have been established in the United States (U.S.) and some European countries. Additionally, serious efforts are being made globally to develop alternative preservatives based on natural products with low or no toxicity. Due to certain limitations which include different results between laboratory and field performance of natural products, difficulties in putting a united agreement globally on setting standards defining the quality of natural products' performance, and the efficacy of these natural compounds when expose to environmental conditions, the progress of the new technologies has been slow. On the other hand, these days the modified wood is produced throughout Europe and other parts of the world. However, in wood modification technologies, the process of transforming from the laboratory phase to production level has been started from the last decades, it is still growing slowly. Higher prices in both special equipment for wood modification process and final wood products, the lack of experience of using the material, consumer perceptions about new materials can be the possible reasons. Thus, the aim of this review is to summarize and cover recent developments studies in different categories of wood preservatives and different process in wood modification. It should be mentioned that this review is not aiming to comprehensively list every study in the field but highlight the trends in contemporary wood science that focus on these areas.

\section{WOOD PRESERVATION}

There is a long history of using preservatives to protect wood and wood products. The benefits of using preservatives are restricted not only to extend service life of structural materials but also to reduce costs and pressure on timberlands by decreasing the number of repairs and replacement of wood products. Wood preservatives provide resistance against insects, fungi, marine borers, bacteria, fire, weathering, and aggressive chemical effects.

According to the Market Research Report (2020) the value of the wood preservatives market is estimated to be $\$ 1.7$ billion by 2025. North America represents the largest portion of the wood preservatives market in 2020 (Market Research Report, 2020). Global wood preservative manufacturers such as Koppers, BASF Wolman GmbH, Borax, KMG Chemicals, KopCoat, and Arxada are putting continuous efforts to develop new chemicals in compliance with rules and regulations of environmental agencies. The choice of treatment is made based on the use defined by internally recognized associations or agencies such as American Wood Protection Association (AWPA) or European Standards for Structural Use (EN 335) (Reinprecht, 2016). This part covers wood preservation system in the last twenty years, how preservatives have been used in new engineered wood products, and how new products are being developed to replace inorganic oil-based preservatives. Historically, wood preservatives mainly included creosote, pentachlorophenol (PCP), and water-based arsenical (Barnes et al., 2001a). The most common first and second generation of preservative systems are the following, Chromated Copper Arsenate (CCA), Creosote, PCP, Ammoniacal Copper Zinc Arsenate (ACZA), Alkaline Copper Quat (ACQ), and Copper Azole (Groenier and Lebow, 2006).

\section{Oil Borne Preservatives}

Heavy duty organic-type (oil-borne) wood preservatives such as creosote and PCP have been extensively applied in the treatment of poles, timber bridge and railway crossties (sleepers) in North America and Europe. Decades ago, the European Union has banned the use of PCP and creosote. Creosote was allowed a 5-year reprieve from its original cancelation date in 2018 (Brient et al., 2020). These two systems have been nominated as Restricted Use Pesticides by the United States Environmental Protection Agency (U.S. EPA) because of disposal concerns (Barnes, 2002). Consequently, current research involving both creosote and PCP are more likely to include best management practices, disposal, recycling, and remediation of treated wood and/or cleaning of contaminated soil.

\section{Creosote}

Creosote is a general term that designates coal tar creosote, coal tar, and coal tar pitch. Creosote is applied to railroad ties, utility poles, pilling, and timber bridge to provide biodegradation protection. The primary chemicals in creosote composition are polycyclic aromatic hydrocarbons (PAHs) (85\%) and phenols (217\%) (Bedient et al., 1984). Approximately, $20-40 \%$ of creosote total weight is attributed to sixteen PAHs, which are major pollutants and potential carcinogens (Goldmark, 2013).

In the United States $70 \%$ of all produced creosote is used to impregnate railway sleepers and crossties. Approximately its $20 \%$ is impregnated to utility poles and their cross arms (United States Environmental Protection Agency [U.S. EPA], 2008). Since creosote has been used for more than two centuries, the literatures have numerous research papers and studies that report its efficiency in protecting wood products 
(Chow and Bajwa, 1998; Barnes et al., 2001b; Slahor et al., 2001; Freeman et al., 2005; Webb et al., 2009; Clausen et al., 2014; Lebow et al., 2015). However, in the last decade the number of studies covering the performance of creosote has significantly decreased. The most current publications include post service activities related to environment protection. Furthermore, in this section the recurrent research from (2016-2021) involving all the aspects of creosote post service has been covered.

Over $95 \%$ of railroad ties produced in the United States are impregnated with creosote (Railroad Ties Association [RTA], 2014). Jones et al. (2019) predicted that in 2030 most of the disposed railway ties (>99\%) and poles (53\%) will be impregnated with creosote. Although creosote does not interact with water and therefore has limited leachability without best management practices (BMPs) during and after treatment. More specifically in preservation facilities, leaching of creosote and consequent soil contamination may occur. Konkler and Morrell (2019) investigated the use of post-treatment steaming to decrease migration of creosote components. The authors concluded that prolonged steaming times after treatment decreased initial losses of creosote components from treated wood.

In older wood preserver's sites, there is widespread soil, sediment, and sludge contamination produced by process, practices, equipment, storage, and waste treatment of chemicals present in creosote composition (Sudell et al., 1992). Consequently, the matrix of organic and inorganic contaminants with very distinct physical-chemical properties makes the remediation of these sites more challenging (Madrid et al., 2019). Larsson et al. (2018) investigated the occurrence of polycyclic aromatic compounds (PAC) on soil and concluded that PAC existed in all investigated areas but in different concentrations.

One of the most practical ways of recovering creosote is to use it as energy by high temperature incineration. On the other hand, operating costs of an incinerator may be relatively high (Magdouli and Foudhaili, 2020). Numerous techniques involving biological, physical and chemical, and thermal processes have been developed with the idea of remediating contaminated sites (Kim et al., 2016; Simpanen et al., 2016; Trine et al., 2019). For instance, Bezza and Chirwa (2016) used a biosurfactant to enhance biodegradation of PAHs. The biosurfactant produced in situ promoted desorption and emulsification of hydrophobic contaminants.

Several cleaning up methods have been applied to either mitigate the consequences of the disposal or to recycle the creosote treated material. Konkler and Morrell (2019) studied the use of standard soil to capture heavy metals and PAHs. They reported that the soil in heated-sealed and permeable plastic mesh sachet was able to deflect heavy metals and PAHs migrating from the posts. Covino et al. (2016) investigated the feasibility of decontaminating creosotetreated wood by co-composting with agricultural wastes. The removal rate of polycyclic aromatic hydrocarbons (PAH) ranged from 81 to $97 \%$ based on the compost type after 240 days. Abouelela and Hallett (2021) investigated the use of protic ionic liquid media to decontaminate creosote treated wood. They reported that the non-hydrophobic protic ion liquid was highly effective on removing PAHs from the creosote impregnated in the wood.

Creosote is an important preservative that prolongs the service life of industrial wood products. As for research, numerous techniques have been investigated and implemented to recycle treated wood, and to remediate contaminated areas. The challenges with these methods are related to costs and time.

\section{Pentachlorophenol}

Pentachlorophenol (PCP or simply penta) is a polychlorinated phenol extensively used as a wood preservative, mostly in industrial applications such as hydro poles, cross poles, and railway ties (Butler and Frank, 1991). PCP was introduced as a wood preservative in the 1930's and since then it has been used as a heavy-duty preservative (United States Environmental Protection Agency [U.S. EPA], 2008). It is a widespread environmental pollutant that brings concerns in terms of toxicity to humans and wildlife (Wang et al., 2001). Despite restrictive policies in the use of PCP and other chlorophenols, there was not a substantial decrease in their amount in the environment (Niesler and Surmacz-Górska, 2018). Penta is mixed with petroleum oil, usually diesel or similar oil cuts, and impregnated under pressure into the wood products. The AWPA defines penta-treating as appropriate for round poles used for utility service (American Wood Protection Association [AWPA], 2019a). Currently, few investigations cover the efficiency of penta protection against microorganisms. The most recent research paper by Schauwecker et al. (2020) reported that low level of preservative, decreased moduli of rupture (MOR), and presence of decay in five penta-treated Douglas-fir crossarms after 4560 years of service. Although penta remains as an important preservative for the wood products industry, it may solubilize if the treated wood materials enter in contact with water raising concerns to the environment (Crosby, 1981; Konkler and Morrell, 2019). According to Erickson (2021) by the end of 2021 the U.S. EPA proposes to ban all uses of wood treated with PCP. The decision was made based on the termination of production by the only manufacturer of the chemical in North America. Research in penta follows the same pattern seen on creosote, less investigation of its protection efficiency and more studies on recycling, decontamination, and disposal. Techniques to remove and remediate the extension and number of contaminants in the environment have been studied over the years as penta has continuously contaminated soil and water (Hechmi et al., 2016; Hung et al., 2016; Rao et al., 2017; Muhamad et al., 2020). For example, Stratton and Stokes (2016) determined the concentration of chlorinated metabolites 15 years after contamination and sequential remediation. They concluded that the levels of chlorinated phenolic compounds generated by PCP were below detection threshold. Guemiza et al. (2017) investigated the use of counter-current attrition process (CCAP) to remove contaminants from soil including PCP. The CCAP treatment achieved a removal rate of $49 \%$ for PCP and was considered a suitable solution for industrial applications. In Japan, crossarms, timber, utility poles, and ties were surveyed for reuse and/or disposal (Koyano et al., 2019). In the recycle material, the highest residue concentration detected 
was PCP with $3.0 \mathrm{mg} / \mathrm{kg}$. In the waste timber, only $0.20 \mathrm{mg} / \mathrm{kg}$ of PCP was detected. Although the concentrations did not exceed the amount allowed by the Japanese regulations, they provide important information on how to separate treated timber and other industrial wood products. Kraševec et al. (2021) studied non-destructive detection of penta on historical wooden objects. They observed that the level found in the depot air would have low health risk to humans exposed to them.

Research in PCP has been conducted to reduce its impact on human health and environmental pollution. Even though there are regulations in place to terminate the use of penta, the forest products industry still depends on it, due to its role in extending the service life of poles, ties, and cross arms. More research is needed to determine the efficiency and leaching properties of diluted versions of penta.

\section{Copper Naphthenate}

Copper naphthenate $(\mathrm{CuN})$ has been used as a preservative since the beginning of the 20th century. Commercially, $\mathrm{CuN}$ was first developed in 1940 (Groenier and Lebow, 2006). With the regulatory efforts to restrict the use of penta in 1980, the public interest for $\mathrm{CuN}$ was leveraged (Morrell, 2018). Copper naphthenate belongs to the copper carboxylate group and is found in both oil and water-borne systems (Barnes et al., 2005). Copper naphthenate is generated by reacting copper with naphthenic acid, which is a byproduct of oil refining. Copper naphthenate tends to be slightly less effective than penta, however, it is around 10 times less harmful to humans. Because of the regulation's restrictions applied to penta, the interest in copper naphthenate has grown over the years (Morrell, 2018).

From the late 90's to 2000's numerous studies were published on decay, fire and termites' protection, and strength performance of wood treated with CuN by both Mississippi State University and Michigan State University (Dawson-Andoh and Kamdem, 1998; Kamdem et al., 1998; Kamdem and Chow, 1999; Barnes et al., 2001a, 2002; Kirkpatrick and Barnes, 2006). For instance, Barnes et al. (2005) investigated the performance of copper naphthenate during field testing in comparison to other copper carboxylate preservative systems using water-borne, oil-borne, and water dispersible formulations. The authors found that heavy oil carriers outperformed organic solvent and water carriers. In the last five years, few studies were conducted in academia involving performance of CuN during service. Recently, a field test performed in Canada showed that all untreated control either failed or presented severe decay after 10 years in ground contact exposure, while the copper naphthenate $(2 \% \mathrm{Cu}$ in mineral spirits) specimens displayed only low degree of decay on a few occasions. Above ground contact, the samples remained without damage whereas the untreated exhibited high degree of decay (Stirling and Wong, 2019). Lebow et al. (2017) studied the used non-pressure wood preservatives for military applications and used $\mathrm{CuN}$ as reference. Wood treated with $\mathrm{CuN}$ had the lowest weight loss during termites' non-choice test. Most of the research involving development of formulations and concentration of preservatives are restricted to the industry which is constantly seeking for cost effective solutions to prolong the useful life of wood products. Although $\mathrm{CuN}$ has environmental advantages and has shown great performance against decay, creosote and penta still are the most used oil-borne preservatives.

\section{Water Borne Preservatives}

Water-borne chemicals were introduced into the market in the 1950s (Smith, 2019). Their carrier is cost-effective, safe, and normally provides a clean surface on the treated wood (Schultz and Nicholas, 2004). Preserved wood with waterborne chemicals can be painted post-treatment and can also be used to a wider range of applications such as utility poles, residential lumber, and timber as well as for protection of wood composites (American Wood Protection Association [AWPA], 2019a). Water-borne treatments include arsenical, non-arsenical copper, and non-metal preservatives. Numerous studies were conducted on the fungicide, bactericide, insecticide, algaecide, and moldicide performances of water-borne chemicals.

\section{Copper Systems}

Copper is an essential micronutrient for the development of plants and animals. In higher doses, copper may act as a preservative against decay, bacteria, mold, inset, and algae. The use of copper in the preservation industry dates from over hundred years (Freeman and McIntyre, 2009). Lebow (2007) stated that, although the use of borates and other organic biocides have increased over the years, copper is still the most important biocide component used to protect wood. Preston et al. (2008) recognized the most general types of copper-based wood preservatives. One of them is the system that uses chromium as a corrosion inhibitor, fixation agent, and co-biocide, for instance CCA, and copper naphthenate. Another type is copper preservatives that contain nitrogen base as solubilizer, fixation agent and corrosion inhibitor, exemplified by ammoniacal copper arsenate (ACA), ammoniacal copper zinc arsenate (ACZA), ammoniacal copper citrate, copper azole (CA), copper HDO, and alkaline copper quat (ACQ). Numerous manuscripts and research papers have been published in the last decade on the use of copper-based systems to extend the usability of wood and wood-based products in different parts of the world for distinct applications.

The most important wood preservatives in the last 70 years have been water-borne metallic arsenicals, such as CCA and ammoniacal copper arsenate (ACA) (Smith, 2019). In the literatures, there are a wide range of research paper in the topics of degradation, durability, chemical migration, leaching, remediation, recycling, and disposal (Srinivasan et al., 1999; Clausen, 2000; Zaidon et al., 2003; Townsend et al., 2004; Virkutyte et al., 2005; Lin et al., 2009; Zelinka and Rammer, 2009; Temiz et al., 2014; Lebow et al., 2015). In New Zealand, Singh and Page (2016) evaluated the service life of CCA-treated pine based on decay progression. The authors concluded that both treated stakes and poles in ground contact with $1.65 \%$ of retention would achieve service life of more than 100 years based on decay progress.

Chromated copper arsenate and other copper-based preservatives have been in the market for many years, consequently their disposal brought many challenges which promoted the studies in the area of recycling, recovery, and remediation of copper-treated wood (Humar et al., 2004; 
Sierra-Alvarez, 2009; Kartal et al., 2015; Parker, 2017; Akgul and Akgul, 2018). In a study by Tascioglu et al. (2016) the biological, physic-mechanical, and thermal properties of wood-plastic produced from recycled CCA treated wood were assessed. They found higher strength, dimensional stability, and biological resistance against termites and decay in treated samples. In Brazil, where there are no restrictions in the use of CCA (Vidal et al., 2015), Ferrarini et al. (2016) investigated the use of acid leaching to decontaminate CCA-treated eucalyptus wood. They concluded that hot water with sulfuric acid was effective in removing CCA from treated wood.

Chromated copper arsenate and ACA contain substances that are harmful to the environment, other copper-based preservatives were developed to serve as an alternative for external applications namely copper azole (CA) and alkaline copper quaternary (ACQ). According to United States Environmental Protection Agency [U.S. EPA] (2021) copper azole is a water-based preservative used to protect wood from decay and insect attack, and its uses include millwork, shingles and shakes, siding, plywood, structural lumber, fence posts, building and utility poles, land and freshwater piling, composites, as well as above-ground, ground-contact and fresh and saltwater applications. ACQ is also used to prevent decay and insect attack and has been registered to treat lumber, timbers, landscape ties, fence posts, building and utility poles, land, freshwater and marine pilings, sea walls, decking, wood shingles, and other wood structures (United States Environmental Protection Agency [U.S. EPA], 2021).

The scientific community in the wood protection field has studied the penetration properties, retention, leaching, and resistance to fungi and termites of softwood and hardwoods treated with CA and ACQ (Slahor et al., 1997; Morris et al., 2002; Temiz et al., 2004; Arango et al., 2006; Humar et al., 2006; Yildiz, 2007; Ma et al., 2013). In a study conducted in the Chinese Academy of Forestry, the biological and termiticidal performance of CA and ACQ as surface treatment were investigated for either remedial or supplemental application (Ma et al., 2013). The results showed that the efficacy of the preservative was linked to surface retention, for this reason wood species with low permeability had significant mass losses caused by either termites or white-rot fungus. In a more recent study, Sivrikaya et al. (2017) studied the weathering performance of wood treated with copper azole in combination with water repellents. The results showed that wood treated with $\mathrm{CA}$ and water repellents improved the leaching characteristic and inhibited color change. Copper ammonium acetate complex commercially known as COMPTEC $^{\mathrm{TM}}$ was developed by Chemical Specialties Inc., with the objective of incorporating a drying oil to a copper preservative to resist biological action and water uptake (Roos and Archer, 2004). According to González-Laredo et al. (2015), the drying oil in the wood decreases water absorption and increases dimensional stability, which preserves the wood mechanical strength. Also, the copper ammonium acetate-oil complex may be added to green wood either in solid or flaked form.

Alkaline copper quat (ACQ) is a combined formulation that contains $50-67 \%$ of copper oxide and 33 to $50 \%$ of quaternary ammonium compound with multiple variations on its composition namely ACQ-A, ACQ-B, ACQ-C, and ACQ-D
(Kirker and Lebow, 2021). ACQ is one of the several preservatives that were developed to be an environmentally friendly substitute for CCA. Lebow (2007) pointed out that ACQ can penetrate into wood species that are classified as hard to treat. For instance, Pang et al. (2017) investigating the effect of incising on the resistance of ACQ concluded that the service life of ACQ treated wood be more than 50 years based on leaching test results. More recently, Adnan et al. (2021) investigated the impact of ACQ treatment on surface quality and bonding performance of hardwood and CLT elements. The results showed that ACQ treatment does not affect block shear and strength of hardwoods and CLT samples. Copper HDO (CX-A or copper xyligen) is an amine copper-based wood preservative that has been utilized in Europe for over 30 years. The active ingredients are copper oxide (61.5\%), boric acid (24.5\%), and copper-HDO (Bis(N-cyclohexyldiazeniumdioxy copper) (14.0\%) (Lebow, 2013). According to Schultz and Nicholas (2007), copper HDO is stable, but the borate is leached relatively quickly, and the noncomplexed copper also can also leach. This system has shown satisfactory aboveground performance in research tests, but low efficacy in ground-contact in areas where copper-tolerant fungi were present. Kim et al. (2010) evaluated HDO's ability to protect pine samples from termites' attack. The results indicated not only protected the samples, but their performance was comparable to CCA-C. Barnes et al. (2009) observed that southern pine pressure treated with copper HDO had similar properties to untreated southern pine and therefore it could be used in structural applications.

Copper has also been applied in fine particles in the form of basic $\mathrm{CuCO}_{3} \mathrm{Cu}(\mathrm{OH})_{2}$ for wood protection (Cookson et al., 2010; Civardi et al., 2015). These wood preservatives commonly referred as micronized copper was approved by the International Codes Council Engineering Service (ICC ES) and started being applied after 2010. In terms of performance efficiency, micronized copper systems have either similar or superior results when compared to ionic copper-based systems for protecting wood from biodegradation (Pantano et al., 2018). According to Schmitt et al. (2014), micronized copper formulations have lower production costs, higher resistance to both leaching and corrosion of stainless steel and hot-dipped galvanized fasteners. Additionally, since particulate formulas are more concentrated in copper, they have lower shipping costs (Freeman and McIntyre, 2009; Freeman et al., 2013). Micronized copper azole, micronized copper quat, and nanoparticle formulations of copper oxide and zinc oxide have been applied into many wood and woodbased products (Lim et al., 2020a,b; Shiny and Sundararaj, 2021). Because of their leaching resistance, they have shown excellent durability performance (Kartal et al., 2009; Ozgenc et al., 2012; Nguyen et al., 2013). Copper preservatives prolong the service life of wood products which has a positive impact on the conservation of timberlands and forests. However, the disposal of copper-treated wood may pose a challenge to manufacturers and users.

\section{Borates}

Borate preservatives are highly soluble and easily leached. Borate treated wood is recommended only for above ground applications protected from liquid water. Borates have low 
mammalian toxicity but are sufficiently effective against wooddestroying insects and fungi (Williams, 1996). Because of its solubility and mobility, borates can be applied to wood species that are classified as hard to treat. Borate formulations include boric acid, or, usually, disodium octaborate tetrahydrate (DOT), sodium tetraborate and sodium pentaborate (Freeman et al., 2013). The AWPA P25-16 standard recommends a retention of $2.7 \mathrm{~kg} / \mathrm{m}^{3}$ for pretreatment of crossties and $4.5 \mathrm{~kg} / \mathrm{m}^{3}$ for applications above ground contact and protected from liquid water (American Wood Protection Association [AWPA], 2019b).

The use of borates has been extensively investigated nationally and internationally in the last 25 years as a preservative and fire retardant (Thevenon et al., 1997, 1998; Baysal et al., 2006; Lyon et al., 2007; Yuksel et al., 2014; Gillenwaters et al., 2018; Yan and Morrell, 2019). Copper chromium boron (CCB) preservatives is an alternative to CCA and has been widely used in Europe (Icimoto et al., 2013). The disadvantage of using CCB and other preservatives is high leachability when expose to high humidity (Koch and Sheard, 1991). The restriction for indoor applications was lifted through the developments of complex formulations (James and Edwin, 2019). The wood preservation industry has investigated and developed solutions to either decrease or improve the leachability of boron-based preservatives. For example, Lloyd et al. (2005) developed a leach-resistant borate preservative that provided resistance against insect and fungal attack in ground contact and exterior applications.

Mohamad-Nasir et al. (2019) investigated the durability of Malaysian timber species treated with DOT. Results indicated that the preservative protected all samples against termites and white-rot fungi. In fire protection, Yu et al. (2017) studied the effects of boric acid and borax on fire resistance of bamboo filament. The results showed that borax had a better performance on restraining the heat release than boric acid. Borates have also shown satisfactory preservative performance when used in combination with fast releasing DOT and less soluble zinc borate (ZnB) (Uysal et al., 2018). Uysal (2016) examined the efficiency of borate mixtures with different levels of solubility to provide threshold levels of boron into wood samples. The author concluded that boron levels were distinct in the outer zone and all the mixtures provided high protection against internal decay in the outer zone.

In France, Lyon et al. (2009) tested the resistance of wood treated with ammonium borate oleate to fungi decay. The four solutions investigated exhibited efficiency against fungi, except for pine samples exposed to the brown rot fungus (Coniophora puteana). In the case of surface protection, Fogel and Lloyd (2002) found that borate-containing products significantly decreased in mold growth compared to construction products without borates. In Turkey, Kucuktuvek et al. (2020) evaluated the weathering performance of wood impregnated with ammonium tetrafluoroborate (ATFB), ammonium pentaborate (APB) and boric acid (BA) and coated with a layer of liquid glass (LG). The authors concluded that samples impregnated with borate solutions were more color stable than the controls.

Borates have also proved to be an efficient ingredient for dual protection. Lloyd et al. (2018) studied the application of dual borate and $\mathrm{CuN}$ treatment of timber bridges. The authors pointed out that the addition of borate to protect heartwood provided significant increase in bridge tie useful life, therefore it can be used either with creosote or copper naphthenate.

Preservative manufacturers such as Nisus, Koppers and KoCoat have developed new borate formulations with the objective of protect wood in ground above contact (Marks et al., 2002; Lloyd, 2013; Zhang et al., 2014). For instance, Zhang et al. (2012) created a micronized boron preservative that had both wood preservative and flame retardant composition with low leachability. In Uruguay, the developed micronized zinc borate inhibited mold growth and prevent leachability while maintained protection against decay fungi (Ibañez et al., 2019).

Borates have a great performance in interior applications, but its fixation problem restrain its use in outdoor exposure. Although fixation of boron compounds has been extensively studied (Huang et al., 2018; Murthy et al., 2019; Verly Lopes et al., 2020; Bhatt and Tripathi, 2021; Ibañez et al., 2021), it is still recommended only for interior purposes by AWPA (American Wood Protection Association [AWPA], 2019c). As mass timber products become more popular in North America, borates may serve as a great preservative as well as fire retardant. More research needs to be done to determine the application of borates for engineered wood products.

\section{Natural Wood Preservatives}

Traditional preservatives including CCA have been banned in many European countries as well as the United States due to the toxic components including chromium and arsenic. It is well documented that a common wood preservative, for example, CCA contains considerable level of arsenic after its disposal resulting in the soil and groundwater contamination. This has led to a ban on its use by several countries in response to CCA toxicity (Khan et al., 2006; Hawley et al., 2009). Thus, there is an ongoing need of non-toxic preservatives to improve wood preservation technology to replace synthetic and inorganic compounds with organic biocides or natural wood preservatives (Broda, 2020). Environmentally friendly wood preservative has recently emerged as a common acceptable alternative for wood preservation industry. This becomes more important since the demand for environmentally friendly wood preservative has been shown to increase by environmental organizations, consumers, and authorities (Alfredsen et al., 2004).

Depending on the origin of the compounds, natural wood preservatives can be categorized into different sections such as plant extracts, essential oils, waxes, resins and tannins from bark, heartwood extractives, chitosan, etc. The antimicrobial agents which are aromatic and non-aromatic compounds are produced by plants. Some of these products include phenols, terpenoids, alkaloids, lectins and polypeptides and they can be used in different applications (Broda, 2020). In several studies, derivatives from various plant parts including bark, wood, leaves, seeds, and fruits, have been investigated for their wood protection properties (Yang, 2009). In different studies, extracts from cinnamon leaves have been effective against wood decay fungi and termites (Wang et al., 2005; Cheng et al., 2006; Lin et al., 2007; Maoz et al., 2007). Matan and Matan (2007), also investigated the highly effective of cinnamon oil and clove oil 
against mold growth on the surface of rubber wood. Lemon grass, rosemary, tea tree and thyme also contain essential oils which are effective against mold on wood (Yang and Clausen, 2007). Table 1 which has prepared by Singh and Singh (2012) categorized the natural preservatives, especially essential oils with details. One of the essential oils as an effective organic biocide, particularly when used in combination with other organic products is Linseed oil. Linseed oil can be used as protective coatings for a long-time protection. Linseed oil-boron and tall oil-boron combination treatments have given very effective results against fungi and termites (Lyon et al., 2007; Temiz et al., 2008). The heartwoods of durable species such as black locust (Robinia pseudoacacia L.) and African padauk (Pterocarpus soyauxii Taub.) contain natural extractive compounds which have antifungal activities (Sablik et al., 2016). The bark extract from mimosa (Acacia mollissima) and quebracho heartwood extract (Schinopsis lorentzii) contains condensed tannins (proanthocyanidins or polyflavonoid tannins). These condensed tannins are so effective against both white and rot fungi (Tascioglu et al., 2013; González-Laredo et al., 2015) especially in indoor applications (Tascioglu et al., 2012). Other extractive compounds from plants, such as diols, may be effectively used as coatings for wood protection in outdoor applications (Teacă et al., 2018). Chitosan which is a 1-4linked polymer of 2 -acetamido-2-deoxy- $\beta$-D-glucose derived from chitin has also antimicrobial and antifungal properties. Chitosan has been raised the attention of several scientists during the past decades as an excellent environmentally friendly wood preservative agent (Eikenes et al., 2005a,b; Torr et al., 2005; Hussain et al., 2013; Khademibami et al., 2020a). Factors that impact the antifungal activities of chitosan are the molecular weight, degree of deacetylation, and source of chitosan as well as fungi or bacteria that interact with chitosan and its derivatives (Xu et al., 2010; Ing et al., 2012). The antifungal activity of various concentrations of Low molecular weight chitosan $(0.25,0.50$, and $0.75 \%$ ) in three active strains of fungal (Aspergillus niger, Aspergillus flavus, and Penicillium chrysogenum) in wooden artifacts samples was also reported by El-Gamal et al. (2016).

It is well observed that replacement of effective preservatives such as CCA is the time-consuming process (Schultz and Nicholas, 2007). Finding effective bioactive sources, development of formulation and treatment processes in which how target natural compounds eliminate wood deteriorating organisms including fungi, bacteria and termites are needed more investigations and considerable exploration. Furthermore, suitable formulations and treatment methods should be applied to achieve the significant biocides penetration within wood cell walls in order to increase their efficacy and decrease the cost. There are two main issues that can be addressed for natural products as wood preservatives. Firstly, retention of organic biocides into impregnated wood particles, and secondly, susceptibility of natural wood preservatives to biodegradation (Singh and Singh, 2012). Unlikely, the exposure of treated wood to moisture has been shown to result in a significant increase in leaching and decrease in antifungal activity or prevention microbial attack organic biocides on wood products (Larnøy et al., 2006; Treu et al., 2009; Khademibami et al., 2020b). It is well documented that certain additive in combination with organic biocides resulted in an increase the functionality of biocides and their retention rate into wood cells (Schultz et al., 2006; Torr et al., 2006). The efficient way retaining biocides within the impregnated wood is to use co-impregnate agents for fixation of organic biocides which is facilitated by cross link biocides to polymers in the wood cell walls. Suitable refinements as well as cost-effective treatments are facilitated by appropriate understanding of the mode of action of different natural compounds. The aforementioned results can be used to select fit-to-purpose agents and develop tools for possible integrated approaches linked to natural compounds and other agents, including antagonistic fungi.

\section{Newer Preservative Systems}

Currently, because of concerns with the potential contamination of air, soil, and water by heavy duty treatments, the wood preservative market is constantly developing new solutions that address the degradation problem using environmentally friendly ingredients (Marx, 2013; Mars et al., 2015; Richardson and Hodge, 2016; Warburton et al., 2017; Hughes et al., 2018; Arumugam et al., 2021). Newer preservative systems are only marketed for above ground exposure. They do not include metal in their compositions. These preservatives rely solely on organic pesticides for wood protection including triazoles, benzimidazoles, isothiazolones, sulfamides, carboxamides, or 3-iodo-2-propynyl-butylcarbamate (IPBC) and 4,5-dichloro-2N-Octyl- 4-Isothiazolin-3-One (DCOI) (Reinprecht, 2016). All these synthesized organic biocides are efficient against numerous wood damaging fungi, and they may also offer protection against termites (Bota et al., 2010; Nicholas, 2018; Singh and Page, 2020; Mehramiz et al., 2021). Table 2 shows the most common wood preservatives and their respective efficacy against fungi and insects. Cost effective and durable water-borne organic systems are difficult to develop in some applications, especially in areas of high deterioration hazards or for ground contact uses (Schultz et al., 2014). Therefore, traditional first- and second-generation preservatives will still be applied for heavy duty applications in order to prolong the service life of wood structures and materials. Continuous research in recycling and disposal are necessary to protect health and the environment.

\section{Wood Coatings}

Wood coatings are used to protect the surface of wood against biotic and abiotic factors. In the case of exterior wood coatings, they are primarily designed to resist weathering effects. Coatings are also designed for esthetic purposes where the wood is exposed without compromising its service-life. The mechanism of action of wood coatings is divided in two categories namely film forming and penetrating (Williams, 1999). Film forming such as paints and solid-body stains contain pigments that protect wood from discoloration caused by sunlight (Feist, 1990). Penetrating coatings consist of water repellents, clear stains, preservative, and surface treatments. They usually contain oil or resin in their composition to seal the wood surface and a solvent to facilitate absorption into the cells (Daniel et al., 2004).

The efficiency of a surface treatment in protecting the wood substrate is highly attributed to its ability to cover and adhere to 
TABLE 1 | Summary of natural compounds.

\begin{tabular}{|c|c|}
\hline & Natural wood preservatives \\
\hline \multirow[t]{16}{*}{ Essential oils } & Essential oil from cinnamon leaves \\
\hline & $\begin{array}{l}\text { Essential oils from Japanese ceder (Cryptomeria japonica) } \\
\text { heartwood }\end{array}$ \\
\hline & Anise oil, lime oil, and tangerine oil \\
\hline & Essential oils from lemongrass, rosemary, tea tree, and thyme \\
\hline & Cinnamon oil \\
\hline & $\begin{array}{l}\text { Essential oil compounds and plant extracts; cinnamaldehyde, } \\
\text { cinnamic acid, cassia oil, and wood tar oil }\end{array}$ \\
\hline & Essential oil from fruit peel of citrus \\
\hline & $\begin{array}{l}\text { Essential oils from Japanese ceder (Cryptomeria japonica) } \\
\text { heartwood }\end{array}$ \\
\hline & Cinnamon (Cinnamomum osmophoeum) \\
\hline & Cinnamon and clove oils \\
\hline & Hinau (Elaeocarpus dentatus) leaf extract \\
\hline & $\begin{array}{l}\text { Cinnamaldehyde in combination with antioxidants propyl gallate, } \\
\text { octyl gallate, quercetin, and eugenol, catechin }\end{array}$ \\
\hline & Cinnamaldehyde, eugenol \\
\hline & $\begin{array}{l}\text { Twelve essential oils screened, including eugenol and oil from } \\
\text { cinnamon leaf and germanium }\end{array}$ \\
\hline & $\begin{array}{l}\text { Plant-derived oils (almond bitter, anise, basil, bay, caraway, } \\
\text { cardamom, cedar, celery, chamomile, cinnamon, citronella, clove, } \\
\text { coriander, cumin, dill, eucalyptus, fennel, ginger, grapefruit, lemon, } \\
\text { lime, mint, parsley, peppermint, pepper, rose, spearmint, sweet } \\
\text { orange, thyme, turmeric, juniper, winter green, tall, and pine oils in } \\
\text { combination with silicone-based polymer }\end{array}$ \\
\hline & $\begin{array}{l}\text { Oxygenated aromatic essential oil compounds- } 22 \text { essential oil } \\
\text { phenols, phenol ethers, and aromatic aldehydes }\end{array}$ \\
\hline
\end{tabular}

Waxes, resins and tannins from bark

\section{Extractives}

Miscellaneous

\section{Boron-linseed oil combination treatment}

Tannins from the bark of Southern pine

Aleppo pine leaves and bark

Bark from six species of wood

Guayule (Parthenium argentatum Gray)

Pinus bruita bark extracts

Extractives of Milicia excelsa and Chlorophora excelsa Heartwood extract of Milicia excelsa and Erythrophleum suaveolens

Extract from Taiwania (Taiwania cryptomerioides) Lignans and glycorides from Gmelina arborea hertwood

Heartwood extractive of Thuja plicata and Chamaecyparis nootkatensis

Valonia extract, sumac leaf extract and pine bark extract

Extract of herbaceous plant, Inula viscose in combination with cinnamon oil, carvacol or thymol

Heartwood extractive of Prosopis juliflora

Australian native tree (Eremophila mitchelli)

Extract from white cypress pine

Chitosan

Silicon compounds

Trichoderma extracts

Lactobacillus extracts

\section{Uses}

Wood decay fungi (nutrient medium)

Wood decay fungi (nutrient medium)

Molds on rubberwood (dip treatment on wood)

Mold growth on yellow pine (dip and vapour treatment on wood)

Ponderosa pine (dip treatment on wood)

Brown, white rot decay fungi and termites (pressure treatment on wood)

Fungi and termite (nutrient medium)

Wood decay and tree pathogenic fungi (nutrient medium)

Wood decay fungi (nutrient medium)

Mold fungi on rubberwood (nutrient medium and dip treatment)

Brown rot fungi (nutrient medium)

White rot and brown rot fungi (nutrient medium)

White rot and brown rot fungi (nutrient medium)

Mold, sapstain and decay fungi (nutrient medium and radiata pine pressure treatment)

Mildew, termites and insects on wood (the method of treatment not disclosed)

White rot and brown rot (nutrient medium)

Japanese cedar, beech and pine against termites (pressure treatment)

Brown and white rot fungi (pressure treatment)

Dip treatment

Mold, stain, brown and white rot fungi (nutrient medium)

Decay fungi, termites and marine borers (pressure treatment)

Brown and white rot (pressure treatment)

Fungi, insects and marine borers (pressure treatment)

Brown and white rot fungi (pressure treatment)

White and brown rot fungi (nutrient medium) Termite

White rot (nutrient medium)

Termite and brown rot (pressure treatment)

White and brown rot fungi (pressure treatment on wood) White and brown rot fungi (pressure treatment on pine wood)

White rot, brown rot, mold and termite (durability test without pressure treatment)

Termites

Termites

Sapstain, mold and wood decay fungi (nutrient medium and dip and pressure treatment on wood)

Decay fungi

Sapstain and basidiomycetes Sapstain
References to work

done

Wang et al. (2005)

Cheng et al. (2006)

Matan and Matan (2008)

Yang and Clausen (2007)

Li et al. (2008)

Kartal et al. (2006)

Macias et al. (2005)

Cheng et al. (2005)

Cheng et al. (2006)

Matan and Matan (2007)

Rickard et al. (2009)

Hsu et al. (2007)

Cheng et al. (2008)

Singh and Chittenden (2008a)

Glassel and Mellema (2006)

US patent no. US 200601

23341A1

Voda et al. (2003)

Lyon et al. (2007)

Laks et al. (1988)

Passialis and Voulgaridis (1999)

Yang et al. (2004)

Nakayama et al. (2001)

Nemli et al. (2006)

Extractives

King and Grundon (1949)

Onuorah (2000)

Chang et al., 2001, 2003

Kawamura et al., 2004;

Kawamura and Ohara, 2005

Taylor et al. (2006)

Sen et al. (2009)

Maoz et al. (2009)

Sirmah et al., 2009a,b

Scown et al. (2009)

French et al. (1979)

Miscellaneous

Kobayashi and Furukawa

(1996) and Chittenden

et al. (2004)

Maoz and Morrell (2004),

Eikenes et al., 2005a,b,

and Torr et al. (2005)

Singh et al. (2008a)

Weigenand et al. (2008)

and Panov and Terziev (2009)

Bruce and Highley (1991)

Singh and Chittenden (2008b) 
TABLE 2 | Efficacy of biocides against fungi and insects.

\begin{tabular}{lccc}
\hline Biocide & \multicolumn{2}{c}{ Efficacy } \\
\cline { 2 - 3 } & Fungicide & Insecticide \\
\hline Boron compounds (boric acid, borax. ..) & + & + \\
Carbamates (IPBC. ..) & + & \\
Copper inorganic compounds (copper oxide, ...) & + & \\
Copper naphtenates and citrates & + & \\
Creosotes & + & + \\
Isotiazolones (DCOIT,) & + & \\
N-organodiazeniumdioxy-metals (Cu-HDO,.) & + & $(+)$ \\
Quarternary ammonium compounds - QAC (DDAC,.) & + & $(+)$ \\
Sulfamides (dichlofluanid, tolylfluanid,.) & + & \\
Triazoles (propiconazole, tebuconazole,.) & + & \\
\end{tabular}

Modified from Reinprecht (2010). +, basic biocidal activity; (+), additional biocidal activity.

the wood surface. A high-performance coating should repel water without trapping it into the wood. If a finish traps water in the wood, it can lead to fungal development. Lu (2019) developed an exterior wood coating with crosslinking polyvinyl acetate technology intended to improve water resistance. Pandit et al. (2020) studied the use of titanium dioxide $\left(\mathrm{TiO}_{2}\right)$ nanoparticles and perfluorooctyltriethoxysilane (PFOTS) to improve water repellency on wood surface. The authors pointed out that the method not only promoted excellent water repellency but also increased thermal and chemical stabilities.

Although coatings are not intended to protect wood from decay, there are some formulations include biocide in their composition to inhibit fungal growth (Bobadilha et al., 2020; Mustata et al., 2021). Stirling et al. (2011) investigated the biocidal performance of various wood coating formulations. The authors concluded that combinations of propiconazole with 3-iodo-2propynyl butylcarbamate (IPBC), as well as propiconazole, IPBC, and thiabendazole were the most effective treatments against fungal growth. In Australia, Moon et al. (2014) developed a light organic solvent preservative (LOSPs) product with a new composition that used acrylic as resin. The invention allowed the application of other protective coating without penetration of the preservative.

The wood protection industry has developed surface treatments to protect timbers and wood-based materials from weathering and mechanical degradation (Costin and Costin, 2009; Kingma et al., 2010; Kuang and Zhang, 2018). They may be used for temporary protection of wood elements specifically during construction. When pressure treatment is not a practical solution, coatings may be applied to protect wood and wood-based products from deterioration. The combination of pressure treatment and finishes are also desired to extend service of structures.

\section{WOOD MODIFICATION}

During the last few years, the environmental pressures have been increasing which have led to significant changes in the field of wood protection. Thus, modern technologies performing by either thermal or chemical modifications have programmed according to ban of biocide products.

In addition, wood modification has become new alternative for wood preservation to change the properties of wood material by describing the application of chemical, mechanical, physical, or biological methods. Modification is emerged to increase the quality of wood materials associated with the moisture sensitiveness, low dimensional stability, hardness and wear resistance, low resistance to bio-deterioration against fungi, termites, marine borers, and low resistance to UV irradiation. Currently, wood modification is applied to enhance the physical, mechanical, or esthetic properties of the sawn timber, veneer or wood particles that can be used in wood composites production. Disposal materials that produce as a result of above process at the end of a product's life cycle have been shown to exhibit no environmental hazards in comparison to unmodified wood. According to Hill (2006) wood modification is the process involves in the action of a chemical, biological, or physical characteristic, leading to a desired property improvement under the service life of the modified wood. The products of wood modification process have not been observed any toxicity reaction under service conditions, as well as toxic substances resulted in their release during service, end of life cycle, disposal or recycling of the modified wood. Non-biocidal mode of action should be applied when the purpose of wood modification is to increase resistance to biological attacks.

Dimensional stability, hygroscopicity, and biological resistance of wood have been observed to enhanced using wood modification because this method alters wood cell components during thermal processing (Kamdem et al., 2002). In addition, an increase in density, hardness, bending strength and stiffness, and termite durability was observed in pine wood as a result of the post heating after densification (Esteves et al., 2017). These results showed that the quality and dimensional stability of the non-durable and low durable wood species could be improved using wood modification. Therefore, weak points of the wood material that are mainly related to low dimensional stability, moisture sensitivity, hardness and wear resistance, low resistance to bio-deterioration against fungi, termites, marine borers, and low resistance to UV irradiation improve by applying modification. Three most important aspects of the entire wood modification mechanism against fungi biodegradation are: (1) modified wood has lower equilibrium moisture content, so it is harder for fungi to obtain the moisture required for decay, (2) The entrance of decay fungi is physically blocked from the micro pores of the cell walls in modified wood, and (3) specific enzymes involved in fungi growth is inhibited in modified wood (Hill, 2006, 2009; Rowell et al., 2009; Rowell, 2016). Wood modification can be done by different process such as chemical processing (acetylation, furfurylation, resin impregnation etc.), thermohydro processing, and thermo-hydro-mechanical processing (Sandberg et al., 2017). Chemical, thermal and impregnation modification are the three methods that used commercially (Hill, 2011). Europe has become world leader in the development of commercial wood modification technologies in the past decade. Currently, near 300,000 to $400,000 \mathrm{~m}^{3}$ of modified wood is 
produced throughout Europe and other parts of the world (Militz, 2020). In this review paper, chemical, thermal, and thermo-mechanical processing are briefly discussed.

\section{Chemical Modification}

Chemical modification of wood $\imath$ has emerged since middle of the 20th century. The final use of material is the main factor to determine the objective of chemical modifications, for example these modifications in solid wood are intended to increase the dimensional stability, mechanical properties, or resistance to biodegradation, whereas modifications in divided wood are aimed to improve behaviors of particles or fibers for utilization for given applications such as composites, paper or new materials.

There are two categories for chemical wood modification technology as an active and passive modification. Chemical modification of wood is considered as an active modification because it results in a chemical change in the cell-wall polymers. Passive modification occurs when the cell walls of wood impregnate with a chemical, or a combination of chemicals, that reacts to form a material that is locked into the cell wall and there is no change in the chemistry of the material (Homan et al., 2000; Hill, 2006; Sandberg et al., 2017; Bi et al., 2021). There are different literature reviews that have been published the chemical reaction systems for chemical modification of wood (Rowell, 1975, 1983, 1991, 1999; Kumar, 1994; Hon, 1996). These chemicals include anhydrides such as phthalic, succinic, malaic, propionic, and butyric anhydride; acid chlorides; ketene carboxylic acids; many different types of isocyanates; formaldehyde; acetaldehyde; difunctional aldehydes; chloral; phthaldehydic acid; dimethyl sulfate; alkyl chlorides; $\beta$-propiolactone, acrylonitrile; epoxides, such as ethylene, propylene, and butylene oxide; and difunctional epoxides. Chemical modification methods have their own characteristics. Currently, acetylation and furfuryl alcoholization modifications' methods are using worldwide for commercial production due to the lower cost, simple manufacturing process, and excellent modification effect (Bi et al., 2021). It is also worth mentioning that the commercial chemical modification (acetylation) of wood in Europe arose from the research in the Netherlands (Hill, 2011).

\section{Thermal Modification}

Development in thermal modification (TM) started from the early of 20th century and it has been continuing in the U.S in 1970. In Latvia, Japan, and Canada the development and commercialization of TM happened in 1970's and 1980's. At the end of 20th century, Europe was trying to develop TM which led to approve of various laws and legislations. Currently, Finland has the highest production of the TM wood (Hill, 2011).

The dimensional stability and durability of timber has been shown to improve using TM which is a well-established commercial technology (Esteves et al., 2006; Huang et al., 2012; Hill et al., 2021). Hygroscopicity also decreases by TM (Metsa"-Kortelainen et al., 2005; Bao et al., 2017). The optimum temperature for the commercial production of TM wood ranged usually between 160 and $240^{\circ} \mathrm{C}$. TM has been observed to result in a material that is darker in color, improved dimensional stability and microbial resistance of wood heated, and reduced in strength, especially fracture resistance (Bekhta and Niemz, 2003; Hill, 2006; Hill et al., 2021). The chemistry of thermal degradation has been different below and above about $150^{\circ} \mathrm{C}$. Thermal modification is well defined when it was employed at above $150^{\circ} \mathrm{C}$ where chemistry of thermal degradation occurred (Yin et al., 2011; Ganne-Chédeville et al., 2012; Endo et al., 2016; Obataya et al., 2019). Above $240^{\circ} \mathrm{C}$ is not recommended for TM due to severe degradation of the wood that cannot be commercially useful. Thermal modification processes have been previously established in North America. In 2012, there were 7 manufacturers of TM in Canada and 10 in the United States (Sandberg and Kutnar, 2016; Sandberg et al., 2017). Thermal modification is applied in two conditions dry and wet (Hill et al., 2021). The significant differences in the characteristics of TM wood under dry or wet conditions are the differences in weight loss, sorption behavior and dimensional stability. Thermally modified wood under dry is more common for formation of crosslinks (especially within the lignin network). The control of moisture content within the cell wall is needed to support exercising fine management over the thermal modification process that can result in an improvement in properties of interest along with minimal negative effects of thermal modification such as brittle and fracture properties (Hill et al., 2021). In order to support aforementioned hypotheses several improved products are commercially available for more in-depth related studies.

\section{Thermo-Mechanical Modification}

Mechanical modification is the compression or densification of the wood in which wood is deformed under mechanical pressure in order to increase its density (Jennings, 2003; Sandberg et al., 2013). Compreg wood, lingostone, lignofol, and staypak are different name of mechanical wood modification products (Kollman et al., 1975). However compressed wood reveals superior strength properties, wood will return to its initial dimensions when it exposes to wet conditions or soaked in water (Dwainto et al., 1997; Ito et al., 1998a,b; Kultikova, 1999; Navi and Girardet, 2000; Heger et al., 2004; Kamke, 2006). Many researchers have been successful to reduce this issue, but the weakness of densified wood was poor bioresistance against microorganisms (Welzbacher et al., 2005). Therefore, combination of thermal modification and mechanical modification have been improved the mechanical, physical properties of wood as well as wood bio-resistance at the same time (Hakkou et al., 2006; Mohebby et al., 2009). This product also produces hydrophobic wood due to the hydrothermal modification (Rapp, 2001; Mohebby and Sanaei, 2005; Tjeerdsma and Militz, 2005). Thermo-hydromechanical process is one of the processes for manufacturing wood-based panels and an efficient way to improve the natural properties and produce stable materials (Navi and Heger, 2004; Sandberg et al., 2013).

\section{CONCLUSION}

\section{Wood Preservation}

Wood preservation research is globally focus on using natural environmentally compatible compounds, nonetheless few wood preservation industrial companies are willing to uptake of these 
natural compounds and their associated technologies. There is human health and environment concern in those compounds with antimicrobial activities, regardless of its origin, associated with their intrinsic biological activity, and therefore, regulatory authorities have been applied for registration of natural compound in many countries. Regulatory roles enforce that any new compound or formulation should be registered prior to manufacturing or sale in which a risk assessment associated with these compounds is determined by direct and in-direct exposures using exhaustive toxicity studies over several years, demanding considerable financial investments. Therefore, conflicts between legislation and registration of new natural compounds can be one of the possible reasons associate with limitation use of the natural preservatives in comparison to the old and toxic generation of preservatives. The other possibilities can be (1) incompatibility of results between laboratory studies and field trial as a result of impaired efficacy of organic biocides in nutrient medium in comparison to the biocide impregnated wood, and (2) limited range of activities for some of natural compounds. For the newer preservatives, the wood protection industry has developed nano and micronized preservatives with objective to improve preservative efficiency without compromising the durability of wood products. There were also recent developments on surface protection systems that not only offer weathering resistance but also inhibit fungal growth specifically mold fungi. With the popularity of mass timber buildings and other engineered wood products, in the future preservatives and coatings are going to be developed to specifically attend the needs and expectations of mass timber elements without compromising the serviceability of metal connections and fasteners.

\section{Wood Modification}

The product performance, the environment, and end-of-life aspects of different modifications are not well investigated to date. To achieve this goal, the entire value chain, from forest through processing, installation, in-service, end-of-life, second and third life, and, eventually, incineration with energy recovery has to be obtained. Modified wood and their products are mainly made in accordance with the interactive assessment of process factors, developed product characteristics, and environmental effects of the timber processing in which environmental effects is associated with amount of energy consumption. However, enhanced characteristics during the use phase could result in a reduction of environmental effects of the timber processing.

\section{REFERENCES}

Abouelela, A. R., and Hallett, J. P. (2021). Hazardous creosote wood valorization via fractionation and enzymatic Saccharification coupled with simultaneous extraction of the embedded polycyclic aromatic hydrocarbons using protic ionic liquid media. ACS Sustain. Chem. Eng. 9, 704-716. doi: 10.1021/ acssuschemeng.0c06414

Adnan, N. A., Tahir, P. M., Husain, H., Lee, S. H., Uyup, M. K. A., Arip, M. N. M., et al. (2021). Effect of ACQ treatment on surface quality and bonding performance of four Malaysian hardwoods and cross laminated timber (CLT). Eur. J. Wood Wood Prod. 79, 285-299. doi: 10.1007/s00107-020-01 609-7
Among all modification techniques, thermally modified wood can now be used in many common applications, but it has its own limitations. Thermally modified wood is suitable for various uses in both interior and exterior uses. However, they are not suitable for timber structures due to their properties and low strength. Thermally modified timber was firstly developed in order to increase the performance and durability of softwoods, and later expanded to boost the performance of hardwoods to eliminate the additional protection for outdoors materials that made by low-durability hardwoods species, for example, birch, aspen, ash, soft maple, tulipwood, and red oak.

Thus, the improvement of existing wood technology has been recently shown to be the main emphasis of wood modification technology studies. The properties of modified wood are more diversified using improved the production process, changed, or supplemented chemical reagents leading to overcoming the original defects. To sum up, economic and environmental parameters are the basis for the improvement of the modified wood properties. Without doubt that research results reporting the efficiency of wood modification in different applications are crucial to maintain and improve its use in the industry. However, there are still some challenges concerning wood modification's application in certain locations, in countries such as United States, wood modification has not been fully explored. More studies are expected to be done to determine wood modification's performance and applications.

\section{AUTHOR CONTRIBUTIONS}

All authors listed have made a substantial, direct, and intellectual contribution to the work, and approved it for publication.

\section{ACKNOWLEDGMENTS}

We appreciate Rubin Shmulsky, for his invaluable assistant in this research. We wish to acknowledge the support of U.S. Department of Agriculture (USDA), Research, Education, and Economics (REE), Agriculture Research Service (ARS), Administrative and Financial Management (AFM), Financial Management and Accounting Division (FMAD) Grants, and Agreements Management Branch (GAMB). This publication is a contribution of the Forest and Wildlife Research Center, Mississippi State University.

Akgul, A., and Akgul, A. (2018). Mycoremediation of copper: exploring the metal tolerance of brown rot fungi. Bioresources 13, 7155-7171. doi: 10.15376/biores. 13.3

Alfredsen, G., Eikenes, M., Militz, H., and Solheim, H. (2004). Screening of chitosan against wood-deteriorating fungi. Scand. J. For. Res. 19, 4-13. doi: 10.1080/ 02827580410017807

American Wood Protection Association [AWPA] (2019a). U1-19 User Specification for Treated Wood. Birmingham, AL: American Wood Protection Association, $5-74$.

American Wood Protection Association [AWPA] (2019b). P25-16 Standard for Inorganic Boron (SBX). Birmingham, AL: American Wood Protection Association, 127. 
American Wood Protection Association [AWPA] (2019c). AWPA Book of Standards. Birmingham: American Wood Protection Association.

Arango, R. A., Green, F. III, Hintz, K., Lebow, P. K., and Miller, R. B. (2006). Natural durability of tropical and native woods against termite damage by Reticulitermes flavipes (Kollar). Int. Biodeterior. Biodegrad. 57, 146-150. doi: 10.1016/j.ibiod.2006.01.007

Arumugam, S., Laganella, D. A., and Stephens, R. W. (2021). Wood Preservatives. U.S. Patent Application 17/280,973. Rochester, NY: Nutrition \& Biosciences USA 2 LLC

Bao, M., Huang, X., Jiang, M., Yu, W., and Yu, Y. (2017). Effect of thermo-hydromechanical densificationon microstructure and properties of poplar wood (Populus tomentosa). J. Wood Sci. 63, 591-605. doi: 10.1007/s10086-017-1661

Barnes, H. M. (2002). "Wood preservation," in Encyclopedia of Pest Management, ed. D. Pimentel (New York, NY: Marcel Dekker), 1-3.

Barnes, H. M., Amburgey, T. L., Freeman, M. H., and Brient, J. A. (2001a). "Performance of copper naphthenate-treated hardwoods," in Proceedings of 32nd Annual Meeting the International Research Group on Wood Preservation, Doc. No. IRG/WP, 01-30269, Nara.

Barnes, H. M., Amburgey, T. L., Hassler, C. C., Slahor, J. J., and Dawson-Andoh, B. (2001b). The durability of yellow-poplar and American beech treated with creosote and borate. For. Prod. J. 51, 51-55.

Barnes, H. M., Amburgey, T. L., and Sanders, M. G. (2005). Performance of copper naphthenate and its analogs as ground contact wood preservatives. Bioresour. Technol. 96, 1131-1135. doi: 10.1016/j.biortech.2004.10.003

Barnes, H. M., Brient, J. A., Freeman, M. H., and Kerr, C. N. Jr. (2002). Performance of copper-naphthenate-treated poles in service. For. Prod. J. 52, 60-63.

Barnes, H. M., Lindsey, G. B., and Hill, J. M. (2009). Effect of copper xyligen treatment on bending properties of wood. Holzforschung 63, 254-256. doi: 10.1515/HF.2009.036

Baysal, E., Sonmez, A., Colak, M., and Toker, H. (2006). Amount of leachant and water absorption levels of wood treated with borates and water repellents. Bioresour. Technol. 97, 2271-2279. doi: 10.1016/j.biortech.2005.10.044

Bedient, P. B., Rodgers, A. C., Bouvette, T. C., Tomson, M. B., and Wang, T. H. (1984). Ground-water quality at a creosote waste site. Groundwater 22, 318-329.

Bekhta, P., and Niemz, P. (2003). Effect of high temperature on the change in color, dimensional stability and mechanical properties of spruce wood. Holzforschung 57, 539-546. doi: 10.1515/HF.2003.080

Bezza, F. A., and Chirwa, E. M. N. (2016). Biosurfactant-enhanced bioremediation of aged polycyclic aromatic hydrocarbons (PAHs) in creosote contaminated soil. Chemosphere 144, 635-644. doi: 10.1016/j.chemosphere.2015.08.027

Bhatt, S., and Tripathi, S. (2021). Effect of silicic acid on boron leaching in plywood manufacture. Appl. Biol. Res. 23, 122-128. doi: 10.5958/0974-4517.2021.00017.3

Bi, W., Li, H., Hui, D., Gaff, M., Lorenzo, R., Corbi, I., et al. (2021). Effects of chemical modification and nanotechnology on wood properties. Nanotechnol. Rev. 10, 978-1008. doi: 10.1515/ntrev-2021-0065

Bobadilha, G. S., Stokes, C. E., Kirker, G., Ahmed, S. A., Ohno, K. M., and Lopes, D. J. V. (2020). Effect of exterior wood coatings on the durability of crosslaminated timber against mold and decay fungi. Bioresouces 15, 8420-8433.

Bota, P., Baines, E., Mead, A., and Watkinson, S. C. (2010). "Antifungal and wood preservative efficacy of IPBC is enhanced by $\alpha$-aminoisobutyric acid," in Proceedings of the 41st Annual Meeting of the International Research Group on Wood Protection, Biarritz.

Brient, J. A., Manning, M. J., and Freeman, M. H. (2020). Copper naphthenateprotecting America's infrastructure for over 100 years and its potential for expanded use in Canada and Europe. Wood Mater. Sci. Eng. 15, 368-376.

Broda, M. (2020). Natural compounds for wood protection against fungi-a review. Molecules 25:3538. doi: 10.3390/molecules25153538

Bruce, A., and Highley, T. L. (1991). Control of growth of wood decay basidiomycetes by Trichoderma spp. and other potentially antagonistic fungi. For. Prod. J. 41, 63-67.

Butler, K. M., and Frank, R. (1991). Pentachlorophenol residues in porcine tissue following preslaughter exposure to treated wood shavings. J. Food Prot. 54, 448-450. doi: 10.4315/0362-028X-54.6.448

Chang, S. T., Cheng, S. S., and Wang, S. Y. (2001). Antitermitic activity of essential oils and components from Taiwania (Taiwania cryptomerioides). J. Chem. Ecol. $27,717-724$.

Chang, S. T., Wang, S. Y., and Kuo, Y. H. (2003). Resource and bioactive substances from Taiwania (Taiwania cryptomeriodes). J. Wood Sci. 49, 1-4.
Cheng, S. S., Lin, H. Y., and Chang, S. T. (2005). Chemical composition and antifungal activity of essential oils from different tissues of Japanese cedar (Cryptomeria japonica). J. Agric. Food Chem. 53, 614-619. doi: 10.1021/ jf0484529

Cheng, S. S., Liu, J. Y., Cheng, E. H., and Chang, S. T. (2008). Antifungal activity of cinnamaldehyde and eugenol congeners against wood rot fungi. Bioresour. Technol. 99, 5145-5149. doi: 10.1016/j.biortech.2007.09.013

Cheng, S. S., Liu, J. Y., Hsui, Y. R., and Chang, S. T. (2006). Chemical polymerization and antifungal activity of essential oils from leaves of different provenances of indigenous cinnamon (Cinnamomum osmophoeum). Bioresour. Technol. 97, 306-312.

Chittenden, C., Kreber, B. M. C., Dowell, N., and Singh, T. (2004). In Vitro Studies on the Effect of Chitosan on Mycelium and Spore Germination of Decay Fungi, Moulds and Staining Fungi. Stockholm: International Research Group on wood protection. Document no IRG/WP 04-10507.

Chow, P., and Bajwa, D. S. (1998). "Weathering effects on the decay resistance of creosote-treated oak," in Proceedings of the $94^{\text {th }}$ Annual Meeting of the American Wood Protection Association, Scottsdale, AZ.

Civardi, C., Schubert, M., Fey, A., Wick, P., and Schwarze, F. W. (2015). Micronized copper wood preservatives: efficacy of ion, nano, and bulk copper against the brown rot fungus Rhodonia placenta. PLoS One 10:e0142578. doi: 10.1371/ journal.pone.0142578

Clausen, C. A. (2000). CCA removal from treated wood using a dual remediation process. Waste Manag. Res. 18, 485-488. doi: 10.1034/j.1399-3070.2000.00151.x

Clausen, C. A., White, R. H., Wacker, J. P., Lebow, S. T., Dietenberger, M. A., Zelinka, S. L., et al. (2014). "Laboratory investigation of fire protection coatings for creosote-treated timber railroad bridges," in Proceedings of the 45th International Research Group on Wood Protection, Section 3, Wood Protecting Chemicals, St. George, UT,

Cookson, L. J., Creffield, J. W., McCarthy, K. J., and Scown, D. K. (2010). Trials on the efficacy of micronized copper in Australia. For. Prod. J. 60, 6-12. doi: 10.13073/0015-7473-60.1.6

Costin, D. J., and Costin, D. Jr. (2009). Ultra Violet Resistant Coating for Wood Products. U.S. Patent Application 12/354,774. Santa Fe, CA.

Covino, S., Fabianová, T., Křesinová, Z., Čvančarová, M., Burianová, E., Filipová, A., et al. (2016). Polycyclic aromatic hydrocarbons degradation and microbial community shifts during co-composting of creosote-treated wood. J. Hazard. Mater. 301, 17-26. doi: 10.1016/j.jhazmat.2015.08.023

Crosby, D. G. (1981). Environmental chemistry of pentachlorophenol. Pure Appl. Chem. 53, 1051-1080. doi: 10.1351/pac198153051051

Daniel, T., Hirsch, M. S., McClelland, K., Ross, A. S., and Williams, R. S. (2004). Clear exterior finishes: finding the balance between aesthetics and durability. JCT Coat. Tech. 1, 42-48.

Dawson-Andoh, B. E., and Kamdem, D. P. (1998). Application of environmental scanning electron microscopy to the study of macrodistribution of copper in copper naphthenate treated hardwoods. Holzforschung 52, 603-606. doi: 10. $1080 / 17480272.2020 .1837948$

Dwainto, W., Inoue, M., and Norimoto, M. (1997). Fixation of deformation of wood by heat treatment. Makuzai Gakkaishi 43, 303-309. doi: 10.1016/j.joms. 2005.04.019

Eikenes, M., Alfredsen, G., Christensen, B., Militz, H., and Solheim, H. (2005a). Comparison of chitosans with different molecular weights as possible wood preservatives. J. Wood Sci. 51, 387-394. doi: 10.1007/s10086-0040659-6

Eikenes, M., Alfredsen, G., Larnoy, E., Militz, H., Kreber, B., and Chittenden, C. (2005b). Chitosan for Wood Protection-State of the Art. Stockholm: The international research group on wood protection. Document no. IRG/WP 05-3037.

El-Gamal, R., Nikolaivits, E., Zervakis, G. I., Abdel-Maksoud, G., Topakas, E., and Christakopoulos, P. (2016). The use of chitosan in protecting wooden artifacts from damage by mold fungi. Electron. J. Biotechnol. 24, 70-78.

Endo, K., Obataya, E., Zeniya, N., and Matsuo, M. (2016). Effects of heating humidity on the physical properties of hydrothermally treated spruce wood. Wood Sci. Technol. 50, 1161-1179. doi: 10.1007/s00226-016-0822-4

Erickson, B. E. (2021). The End of Pentachlorophenol is Near. Chemical \& Engineering News. Available online at: https://cen.acs.org/environment/ pesticides/end-pentachlorophenolnear/99/web/2021/03 (accessed August 9, 2021). 
Esteves, B., Marques, A. V., Domingos, I., and Pereira, H. (2006). Influence of steam heating on the properties of pine (Pinus pinaster) and eucalypt (Eucalyptus globulus) wood. Wood Sci. Technol. 41, 193-207.

Esteves, B., Ribeiro, F., Cruz-Lopes, L., and Idalina Domingos, J. (2017). Densification, and heat treatment of maritime pine wood. Wood Res. 62, 373-388.

Feist, W. C. (1990). Weathering performance of painted wood pretreated with water-repellent preservatives. For. Prod. J. 40, 21-26.

Ferrarini, S. F., Dos Santos, H. S., Miranda, L. G., Azevedo, C. M. N., Maia, S. M., and Pires, M. (2016). Decontamination of CCA-treated eucalyptus wood waste by acid leaching. Waste Manag. 49, 253-262. doi: 10.1016/j.wasman.2016.01. 031

Fogel, J. L., and Lloyd, J. D. (2002). Mold performance of some construction products with and without borates. For. Prod. J. 52, 38. doi: 10.1016/j.biortech. 2006.04.023

Freeman, M. H., Crawford, D. M., Lebow, P. K., and Brient, J. A. (2005). “A Comparison of wood preservatives in posts in southern mississippi: results from a half-decade of testing," in Proceedings of the 101st Conference, (New Orleans, LA: American Wood Protection Association), 136-143.

Freeman, M. H., Kitchens, S. C., and Amburgey, T. L. (2013). "Wood preservative systems containing copper and borates: efficacy and synergy," in Proceedings of the 109th Conference, Vol. 109, (Honolulu, HI: American Wood Protection Association), 226-239.

Freeman, M. H., and McIntyre, C. R. (2009). A comprehensive review of copperbased wood preservatives with a focus on new micronized or dispersed copper systems. For. Prod. J. 58, 6-27.

French, J. R. J., Robinson, P. J., Yazaki, Y., and Hillis, W. E. (1979). Bioassays of extracts from white cypress pine (Callitris columellaris F Muell) against subterranean termites. Holzforschung 33, 144-148.

Ganne-Chédeville, C., Jääskeläinen, A. S., and Froidevaux, J. (2012). Natural and artificial ageing of spruce wood as observed by FTIR-ATR and UVRR spectroscopy. Holzforschung 66, 163-170. doi: 10.1515/HF.2011.148

Gillenwaters, B., Scheffrahn, R. H., and Warner, J. (2018). Prevention of colony establishment by the West Indian Drywood termite using reduced rates of borate and silica dust or solution. J. Econ. Entomol. 111, 2298-2302. doi: 10. $1093 /$ jee/toy 174

Glassel, D., and Mellema, G. E. (2006). Protection of Construction Materials from Pests. “US Patent No. US 200601 23341A1." United States Patent Application Publication.

Goldmark, P. (2013). Brief Science of Creosote. Washington State Department of Natural Resources. Available online at: https://www.dnr.wa.gov/publications/ aqr_cleanup_creosote_brief.pdf (accessed July 22, 2021).

González-Laredo, R. F., Rosales-Castro, M., Rocha-Guzmán, N. E., GallegosInfante, J. A., Moreno-Jiménez, M. R., and Karchesy, J. J. (2015). Wood preservation using natural products. Madera Bosques 21, 63-76. doi: 10.21829/ myb.2015.210427

Groenier, J. S., and Lebow, S. (2006). Preservative-Treated Wood and Alternative Products in the Forest Service. Tech. Rep. 0677-2809-MTDC. Missoula, MT: U.S. Department of Agriculture, Forest Service, Missoula Technology and Development Center, 44.

Guemiza, K., Coudert, L., Tran, L. H., Metahni, S., Blais, J. F., Besner, S., et al. (2017). Counter-current attrition process (CCAP) to remove metals, pentachlorophenol (PCP), dioxins and furans (PCDDF) from the 1-4-mm fraction of contaminated soil. Soil Sediment Contam. 26, 636-650. doi: 10.1080/ 15320383.2017.1397098

Hakkou, M., Petrissans, M., Ceradine, P., and Zoulalian, A. (2006). Investigation of the reasons for fungal durability of heat-treated beech wood. Polym. Degrad. Stabil. 91, 393-397. doi: 10.1016/j.polymdegradstab.2005.04.042

Hawley, E. L., Kresic, N., Wright, A. P., and Kavanaugh, M. C. (2009). Assessing the current and future impacts of the disposal of chromated copper arsenatetreated wood in unlined landfills. J. Air Waste Manag. Assoc. 59, 332-342. doi: 10.3155/1047-3289.59.3.332

Hechmi, N., Bosso, L., El-Bassi, L., Scelza, R., Testa, A., Jedidi, N., et al. (2016). Depletion of pentachlorophenol in soil microcosms with Byssochlamys nivea and Scopulariopsis brumptii as detoxification agents. Chemosphere 165, 547554. doi: 10.1016/j.chemosphere.2016.09.062

Heger, F., Giroux, M., Welzbacher, C., Rapp, A. O., and Navi, P. (2004). "Mechanical and durability performance of THM-densified wood," in
Proceedings of the Final Workshop Cost Action, Environmental Optimization of Wood Protection, Lisbon, 1-10.

Hill, C. (2011). Wood modification: an update. Bioresources 6, 918-919.

Hill, C. A. (2006). Wood Modification - Chemical, Thermal, and Other Processes. Chichester: Wiley and Sons, 260.

Hill, C. A. (2009). Why does acetylation protect wood from microbiological attack? Wood Mater Sci. Eng. 4, 37-45. doi: 10.1080/17480270903249409

Hill, C. A., Altgen, M., and Rautkari, L. (2021). Thermal modification of wooda review: chemical changes and hygroscopicity. J. Mater Sci. 56, 6581-6614. doi: 10.1007/s10853-020-05722-z

Homan, W., Tjeerdsma, B., Beckers, E., and Jorissen, A. (2000). "Structural and other properties of modified wood," in Proceedings World Conference on Timber Engineering, British Columbia.

Hon, D. N.-S. (1996). Chemical Modification of Wood Materials. New York, NY: Marcel Dekker.

Hsu, F. L., Yen, T. B., Chang, H. T., and Chang, S. T. (2007). Antifungal Activity and Synergistic Effect of Cinnamaldehyde Combined With Antioxidants Against Wood Decay Fungi. Stockholm: The International Research Group on Wood Protection. Document no. IRG/WP 07-30445.

Huang, X., Kocaefe, D., Kocaefe, Y., Boluk, Y., and Pichette, A. (2012). Study of the degradation behavior of heat-treated jack pine (Pinus banksiana) under artificial sunlight irradiation. Polym. Degrad. Stab. 97, 1197-1214. doi: 10.1016/ j.polymdegradstab.2012.03.022

Huang, Y., Wang, W., and Cao, J. (2018). Boron fixation effect of quaternary ammonium compounds (QACs) on sodium fluoroborate (NaBF4)-treated wood. Holzforschung 72, 711-718. doi: 10.1515/hf-2017-0201

Hughes, K., Craig, M. A. R. S., and Hughes, A. (2018). Additives for Use in Wood Preservation. U.S. Patent 9,961,895. Vancouver: Arch Timber Protection Ltd.

Humar, M., Bokan, M., Amartey, S. A., Šentjurc, M., Kalan, P., and Pohleven, F. (2004). Fungal bioremediation of copper, chromium and boron treated wood as studied by electron paramagnetic resonance. Int. Biodeterior. Biodegrad. 53, 25-32. doi: 10.1016/j.ibiod.2003.08.001

Humar, M., Bučar, B., and Pohleven, F. (2006). Brown-rot decay of copperimpregnated wood. Int. Biodeterior. Biodegrad. 58, 9-14. doi: 10.1016/j.ibiod. 2006.03.003

Hung, P. C., Chang, S. H., Ou-Yang, C. C., and Chang, M. B. (2016). Simultaneous removal of PCDD/Fs, pentachlorophenol and mercury from contaminated soil. Chemosphere 144, 50-58. doi: 10.1016/j.chemosphere.2015.08.058

Hussain, I., Chittenden, C., and Singh, T. (2013). Scoping antifungal activities of various forms of chitosan oligomers and their potential fixation in wood. J. Chemand Chem. Eng. 7, 1175-1180. doi: 10.17265/1934-7375/2013. 12.012

Ibañez, C. M., Camargo, A., Mantero, C., Faccio, R., Malanga, A., and Rabinovich, M. (2019). Effectiveness of micronizing zinc borate to improve its fungicidal properties. Bioresources 14, 6231-6246. doi: 10.15376/biores.15.1.172-186

Ibañez, C. M., Camargo, Á, Gherscovic, D., and Camera, R. (2021). Application of nanometric acrylics to reduce boron leaching. Pro. Ligno 17, 3-10.

Icimoto, F. H., Ferro, F. S., Varanda, L. D., Souza, A. M., Almeida, D. H., Christoforo, A. L., et al. (2013). Physical and mechanical properties of paricá wood species treated with CCB preservative. Intern. J. Mater. Eng. 3, 8-86.

Ing, L. Y., Zin, N. M., Sarwar, A., and Katas, H. (2012). Antifungal activity of chitosan nanoparticles and correlation with their physical properties. Intern. J. Biomater. 2012, 1-9. doi: 10.1155/2012/632698

Ito, Y., Tanahashi, M., Shigematsu, M., and Shinoda, Y. (1998a). Compressive molding of wood by high pressure steam treatment: II. Mechanism of permanent fixation. Holzforschung 52, 217-221.

Ito, Y., Tanahashi, M., Shigematsu, M., Shinoda, Y., and Ohta, C. (1998b). Compressive molding of wood by high pressure steam treatment: I. development of compressive molded squares from thinning. Holzforschung 52, 211-216.

James, J. P., and Edwin, L. (2019). Effectiveness of copper -chrome - boron as a wood preservative - a short review. Intern. J. Sci. Res. Rev. 8, 4436-4444.

Jennings, J. D. (2003). Investigation the Surface Energy and Bond Performance of Compression Densified Wood. Master's thesis. Blacksburg, VA: Virginia Polymeric Institute and State University, 147.

Jones, A. S., Marini, J., Solo-Gabriele, H. M., Robey, N. M., and Townsend, T. G. (2019). Arsenic, copper, and chromium from treated wood products in the US disposal sector. Waste Manag. 87, 731-740. doi: 10.1016/j.wasman.2019.03.004 
Kamdem, D. P., and Chow, P. (1999). The effect of pressure on retention and bending properties of copper naphthenate and CCA type $\mathrm{C}$ treated hardwoods. Wood Fiber Sci. 31, 128-135.

Kamdem, D. P., Pizzi, A., and Jermannaud, A. (2002). Durability of heat-treated wood. Eur. J. Wood Wood Prod. 60, 1-6. doi: 10.1007/s00107-001-0261-1

Kamdem, D. P., Zhang, J., and Freeman, M. H. (1998). The effect of post-steaming on copper naphthenate-treated southern pine. Wood Fiber Sci. 30, 210-217.

Kamke, F. A. (2006). Densified Radiata pine for structural composites. Maderas Ciencia Tecnol. 8, 83-92.

Kartal, S. N., Green, F. III., and Clausen, C. A. (2009). Do the unique properties of nanometals affect leachability or efficacy against fungi and termites? Int. Biodeterior. Biodegrad. 63, 490-495. doi: 10.1016/j.ibiod.2009.01.007

Kartal, S. N., Hwang, W. J., Imamura, Y., and Sekine, Y. (2006). Effect of essential oil compounds and plant extracts on decay and termite resistance of wood. Holz. Roh. Werkst. 64, 455-461.

Kartal, S. N., Terzi, E., Y $l$ lmaz, H., and Goodell, B. (2015). Bioremediation and decay of wood treated with ACQ, micronized ACQ, nano-CuO and CCA wood preservatives. Int. Biodeterior. Biodegrad. 99, 95-101. doi: 10.1016/j.ibiod.2015. 01.004

Kawamura, F., and Ohara, S. (2005). Antifungal activity of iridoid glycosides from the heartwood of Gmelina arborea. Holzforschung 59, 153-155.

Kawamura, F., Ohara, S., and Nishida, A. (2004). Antifungal activity of constituents from heartwood of Gmelina arborea. Part 1. Sensitive antifungal assay against basidiomycetes. Holzforschung 58, 189-192.

Khademibami, L., Barnes, H. M., Jeremic, D., Shmulsky, R., Bourne, K., and Fatemi, S. A. (2020a). Antifungal activity and fire resistance properties of nano-chitosan treated wood. Bioresources J. 15, 5926-5939.

Khademibami, L., Jeremic, D., Shmulsky, R., and Barnes, H. M. (2020b). Chitosan oligomers and related nanoparticles as environmentally friendly wood preservatives. Bioresources J. 15, 2800-2817. doi: 10.15376/biores.15.2.28002817

Khan, B., Solo-Gabriele, H. M., Jambeck, J., Townsend, T. G., and Cai, Y. (2006). response to comments on release of arsenic to the environment from CCATreated Wood. 2. Leaching and speciation during disposal. Environ. Sci. Technol. 40, 4811-4812. doi: 10.1021/es051471u

Kim, G. H., Hwang, W. J., Yoshimura, T., and Imamura, Y. (2010). Laboratory evaluation of the termiticidal efficacy of copper HDO. J. Wood Sci. 56, $166-168$.

Kim, P., Lloyd, J., Kim, J. W., and Labbé, N. (2016). Thermal desorption of creosote remaining in used railroad ties: investigation by TGA (thermogravimetric analysis) and Py-GC/MS (pyrolysis-gas chromatography/mass spectrometry). Energy 96, 294-302. doi: 10.1016/j.energy.2015.12.061

King, F. E., and Grundon, M. F. (1949). Chlorophorin, a constituent of Iroko the timber of Chlorophora excelsa. Nature 162, 564-565. doi: 10.1038/163564a0

Kingma, A. J., Wagner, E., Graf, K., Menzel, K., Militz, H., Krause, A., et al. (2010). BASF Aktiengesellschaft. Method for Treating Wood Surfaces. U.S. Patent 7,846,508. Ludwigshafen, DE: BASF Aktiengesellschaft.

Kirker, G. T., and Lebow, S. (2021). "Wood preservatives," in Wood Handbook: Wood as an Engineering Material, eds R. J. Ross and J. R. Anderson (Madison, WI: USDA), 15.1-15.26.

Kirkpatrick, J. W., and Barnes, H. M. (2006). Copper naphthenate treatments for engineered wood composite panels. Bioresour. Technol. 97, 1959-1963. doi: 10.1016/j.biortech.2005.08.007

Kobayashi, T., and Furukawa, I. (1996). Impregnation of chitosan-metal salt into full sized timber. J. Antibact. Antifun. Agric. Jpn. 24, 191-193.

Koch, A. P., and Sheard, L. (1991). An Evaluation of CCA, CCB and CCP Preservatives Using a "Sandwich Test". Stockholm: The International Research Group on Wood Protection. Document No IRG/WP/2370.

Kollman, F. P., Kuenzi, E. W., and Stamm, A. J. (1975). "Principle of wood science and technology," in Wood Based Materials, ed. W. A. Cote Jr. (New York, NY: Springer-Verlag), 703. doi: 10.3390/ma12152373

Konkler, M. J., and Morrell, J. J. (2019). Effect of post-treatment steaming on preservative migration from pentachlorophenol-treated wood. Int. Wood Prod. J. 10, 70-77. doi: 10.1080/20426445.2019.1622238

Koyano, S., Ueno, D., Yamamoto, T., and Kajiwara, N. (2019). Concentrations of POPs based wood preservatives in waste timber from demolished buildings and its recycled products in Japan. Waste Manag. 85, 445-451. doi: 10.1016/ j.wasman.2018.12.039
Kraševec, I., Nemeček, N., Lozar Štamcar, M., Kralj Cigić, I., and Prosen, H. (2021). Non-destructive detection of pentachlorophenol residues in historical wooden objects. Polymers 13:1052. doi: 10.3390/polym13071052

Kuang, M., and Zhang, J. (2018). Koppers Performance Chemicals Inc. Sprayon Exterior Coating Copositions for Wood Treatment. Geneva: World Intellectual Property Organization. International Publication Number WO 2018/204195 Al.

Kucuktuvek, M., Toker, H., Turkoglu, T., Gunduz, A., Altay, C., and Baysal, E. (2020). Improving weathering performance of wood by borates impregnation and liquid glass coating. Drv. Ind. 71, 347-354. doi: 10.5552/drvind.2020.1923

Kultikova, E. V. (1999). Structure and Properties Relationships of Densified Wood. M.Sc. thesis. Blacksburg, VA: Virginia Polytechnic Institute and State University, 139.

Kumar, S. (1994). Chemical modification of wood. Wood Fiber Sci. 26, 270-280.

Laks, P. E., McKaig, P. A., and Hemingway, R. W. (1988). Flavanoid biocides: wood preservatives based on condensed tannins. Holzforschung 42, 299-306. doi: 10.1515/hfsg.1988.42.5.299

Larnøy, E., Eikenes, M., and Militz, H. (2006). Evaluation of factors that have an influence on the fixation of chitosan in wood. Wood Mater. Sci. Eng. 1, 138-145. doi: 10.1080/17480270701200562

Larsson, M., Lam, M. M., van Hees, P., Giesy, J. P., and Engwall, M. (2018). Occurrence and leachability of polycyclic aromatic compounds in contaminated soils: chemical and bioanalytical characterization. Sci. Total Environ. 622, 1476-1484. doi: 10.1016/j.scitotenv.2017.12.015

Lebow, S. (2007). "Preservative treatments for building components," in Proceedings of the Forest Products Society Conference, New Orleans, LA, 57-64.

Lebow, S. (2013). Evaluation of Wood Species and Preservatives for Wisconsin Transportation Sign Posts. Wisconsin Department of Transportation Research \& Library Unit. Available online at: https://wisconsindot.gov/documents2/ research/WisDOT-Policy-Research-0092-13-15-brief.pdf (accessed August 15, 2021).

Lebow, S., Lebow, P., Woodward, B., Kirker, G., and Arango, R. (2015). Fifty-year durability evaluation of posts treated with industrial wood preservatives. For. Prod. J. 65, 307-313. doi: 10.13073/FPJ-D-15-00002

Lebow, S. T., Zelinka, S. L., Arango, R. A., Woodward, B. M., Lebow, P. K., Ohno, K. M., et al. (2017). Evaluation of nonpressure wood preservatives for military applications. Paper Presented at the Research Paper. FPL-RP-693, Vol. 693. Madison, WI: US Department of Agriculture, Forest Service, Forest Products Laboratory, 1-32.

Li, S., Freitag, C., and Morrell, J. J. (2008). Preventing fungal attack of freshly sawn lumber using cinnamon extracts. For. Prod. J. 58, 71-81.

Lim, H., Tripathi, S., and Li, M. (2020a). Rolling shear modulus and strength of cross-laminated timber treated with micronized copper azole type C (MCA-C). Constr. Build. Mater. 259:120419. doi: 10.1016/j.conbuildmat.2020.120419

Lim, H., Tripathi, S., and Tang, J. D. (2020b). Bonding performance of adhesive systems for cross-laminated timber treated with micronized copper azole type $\mathrm{C}$ (MCA-C). Constr. Build. Mater. 232:117208. doi: 10.1016/j.conbuildmat.2019. 117208

Lin, C. Y., Wu, C. L., and Chang, S. T. (2007). Evaluating the Potency of Cinnamaldehyde as a Natural Wood Preservative. Stockholm: The International Research Group on Wood Protection. Document no. IRG/WP 07-30444.

Lin, L. D., Chen, Y. F., Wang, S. Y., and Tsai, M. J. (2009). Leachability, metal corrosion, and termite resistance of wood treated with copper-based preservative. Int. Biodeterior. Biodegrad. 63, 533-538. doi: 10.1016/j.ibiod.2008. 07.012

Lloyd, J. D. (2013). Borate Micro Emulsion and Method for Making the Same. U.S. Patent 8,465,780. Rockford, TN: Nisus Corp.

Lloyd, J. D., Brischke, C., Bennett, R., and Taylor, A. (2018). Dual borate and copper naphthenate treatment of bridge timbers-potential cost savings by various performance enhancements. Wood Mater. Sci. Eng. 13, 122-128. doi: 10.1080/ 17480272.2017.1383512

Lloyd, J. D., Fogel, J. L., and US Borax Inc (2005). Wood Preservative Concentrate. U.S. Patent 6,896,908. Valencia, CA: US Borax Inc.

Lu, Z. (2019). Durable, Water Resistant Wood and Wood Composites. U.S. Patent 10,174,179. Red Wing, MN: Ziqiang Lu.

Lyon, F., Thevenon, M. F., Imamura, Y., Gril, J., and Pizzi, A. (2007). Development of Boron/Linseed Oil Combination Treatment as a Low-Toxic Wood Protection: Evaluation of Boron Fixation and Resistance to Termites According to Japanese 
and European Standards. Stockholm: The International Research Group on Wood Protection. Document no. IRG/WP 07-30448.

Lyon, F., Thévenon, M. F., Pizzi, A., and Gril, J. (2009). Resistance to decay fungi of ammonium borate oleate treated wood. Paper Presented at the 40th Annual Meeting of the International Research Group on Wood Protection, Beijing.

Ma, X., Jiang, M., Wu, Y., and Wang, P. (2013). Effect of wood surface treatment on fungal decay and termite resistance. Bioresources 8, 2366-2375. doi: 10.15376/ BIORES.8.2.2366-2375

Macias, F. A., Torres, A., Maya, C. C., and Fernandez, B. (2005). "Natural biocides from citrus waste as new wood preservatives," in Proceedings of the Fourth World Congress on Allelopathy, (Wagga: Charles Sturt University).

Madrid, F., Rubio-Bellido, M., Villaverde, J., Peña, A., and Morillo, E. (2019). Natural and assisted dissipation of polycyclic aromatic hydrocarbons in a longterm co-contaminated soil with creosote and potentially toxic elements. Sci. Total Environ. 660, 705-714. doi: 10.1016/j.scitotenv.2018.12.376

Magdouli, S., and Foudhaili, T. (2020). "Thermal desorption and incineration," in Remediation: Classic and Modern Techniques, The Handbook of Environmental, ed. C. M. Hussain (Croydon: Royal Society of Chemistry), 229. doi: 10.1039/ 9781788016261-00229

Maoz, M., Freitag, C., and Morrell, J. J. (2009). "Potential synergy between natural product extracts for limiting fungal decay," in Proceedings of the International Research Group on Wood Protection, Queenstown. Document no. IRG/WP 09-30495.

Maoz, M., and Morrell, J. J. (2004). Ability of Chitosan to Limit Wood Decay Under Laboratory Conditions. Stockholm: The International Research Group on Wood Protection. Document no. IRG/WP 04-30339.

Maoz, M., Weitz, I., Blumenfeil, M., Freitag, C., and Morrell, J. J. (2007). Antifungal Activity of Plant Derived Extracts Against G. trabeum. Stockholm: The International Research Group on Wood Protection. Document no. IRG/WP 07-30433.

Market Research Report (2020). Wood Preservatives Market by Formulation (Water-Based, Oil-Based, Solvent-Based), Application (Residential, Commercial, Industrial), and Region (North America, APAC, Europe, South America, Middle East and Africa) - Global Forecast to 2025. Available online at: https://www.marketsandmarkets.com/Market-Reports/wood-preservativemarket-26944487.html (accessed December 14, 2021).

Marks, B., Ross, A. S., and Ward, H. A. (2002). Synergistic Combination of Fungicides to Protect Wood and Wood-Based Products from Fungal Decay, Mold and Mildew Damage. U.S. Patent 6,416,789. Hickory, NC: Kop Coat Inc.

Mars, C. A., Cantrell, D. G., Hughes, K., and Hughes, A. S. (2015). Wood Preservative Compositions Useful for Treating Copper-Tolerant Fungi. U.S. Patent 9,023,483. New York, NY: Arch Timber Protection Ltd.

Marx, H. N. (2013). Oil Borne Wood Preserving Composition for Treatment of Poles, Posts, Piling, Crossties and Other Wooded Structures. U.S. Patent Application 13/498,185. Peachtree City: Osmose Inc.

Matan, N., and Matan, N. (2007). Effect of Cinnamon Oil and Clove Oil Against Major Fungi Identified from Surface of Rubberwood (Hevea brasiliensis). Stockholm: The International Research Group on Wood Protection. Document no. IRG/WP 07-30446.

Matan, N., and Matan, N. (2008). Antifungal activities of anise oil, lime oil, and tangerine oil against moulds on rubberwood (Hevea brasiliensis). Int. Biodeterior. Biodegrad. 62, 75-78. doi: 10.1016/j.ibiod.2007.07.014

Mehramiz, S., Oladi, R., Efhamisisi, D., and Pourtahmasi, K. (2021). Natural durability of the Iranian domestic bamboo (Phyllostachys vivax) against fungal decay and its chemical protection with propiconazole. Eur. J. Wood Wood Prod. 79, 453-464. doi: 10.1007/s00107-020-01601-1

Metsa"-Kortelainen, S., Antikainen, T., and Viitaniemi, P. (2005). The water absorption of sapwood and heartwood of Scots pine and Norway spruce heat-treated at 170C, 190C, 210C an 230C. Holz. Roh-Werkst 64, 192-197.

Militz, H. (2020). Wood modification research in Europe. Holzforschung 74:333. doi: 10.1515/hf-2020-0050

Mohamad-Nasir, M. A., Roszaini, K., Salmiah, U., Tumirah, K., and Zaihan, J. (2019). Durability of selected Malaysian wood treated with disodium octaborate tetrahydrate used under hazard class 2 condition. J. Trop. For. Sci. 31, 43-49. doi: 10.26525/jtfs2019.31.1.043049

Mohebby, B., and Sanaei, I. (2005). "Influences of the hydro-thermal treatment on physical properties of beech wood (Fagus orientalis). The international research group on wood protection (IRG)," in Proceedings of the 36th Annual Meeting, 24-28 April, IRG Document No. IRG/WP 05-40303, Bangalore.

Mohebby, B., Sharifnia-Dizboni, H., and Kazemi-Najafi, S. (2009). Combined Hydrothermo- Mechanical Modification (CHTM) as an Innovation in Mechanical Wood Modification. Stockholm: IRG on Wood Protection, 353-362.

Moon, R. P., Mason, A. J., Claridge, G. C., and Gelid, P. E. (2014). Wood Coating Compositions and/or Methods of Treating Wood. Auckland: Arch wood protection (NZ) limited.

Morrell, J. J. (2018). "Protection of wood-based materials," in Handbook of Environmental Degradation of Materials, ed. M. Kutz (Delmar, NY: William Andrew Publishing), 343-368. doi: 10.1016/b978-0-323-52472-8.00017-4

Morris, P. I., McFarling, S. M., and Zahora, A. R. (2002). Treatability of refractory species with amine and amine/ammoniacal formulations of ACQ. For. Prod. J. $52,37-42$.

Muhamad, M. H., Abdullah, S. R. S., Hasan, H. A., and Bakar, S. N. H. A. (2020). Multimedia-sequencing batch biofilm reactor in treating recycled paper mill effluent containing high level of pentachlorophenol: long-term performance, mechanism and kinetic studies. J. Water Process. Eng. 37:101522. doi: 10.1016/ j.jwpe.2020.101522

Murthy, N., Kiran, M. C., Chawla, V. K., Upadhayay, V. K., and Prakash, V. (2019). "Evaluation of new boron fixation system for wood preservation," in Proceedings of the International Journal of Engineering Research and Management (IJERM), Hoboken.

Mustata, F., Rosu, D., Varganici, C. D., Rosu, L., Rosca, I., and Tudorachi, N. (2021). Assessing the thermal and fungal behavior of eco-friendly epoxy thermosets derived from vegetable oils for wood protective coatings. Prog. Organ. Coat. 163:106612. doi: 10.1016/j.porgcoat.2021.106612

Nakayama, F. S., Vinyard, S. M., Chow, P., Bajwa, D. S., Youngquist, J. A., Muehl, J. H., et al. (2001). Guayule as a wood preservative. Ind. Crops Prod. 14, 105-111. doi: 10.1016/s0926-6690(00)00093-5

Navi, P., and Girardet, F. (2000). Effects of thermo-hydro-mechanical treatment on the structure and properties of wood. Holzforschung 54, 287-293.

Navi, P., and Heger, F. (2004). Combined densification and thermo-hydromechanical processing of wood. MRS Bull. 29, 332-336.

Nemli, G., Gezer, E. D., Yildiz, S., Temiz, A., and Aydin, A. (2006). Evaluation of the mechanical, physical properties and decay resistance of particleboard made from particles impregnated with Pinus brutia bark extractives. Bioresour. Technol. 97, 2059-2064. doi: 10.1016/j.biortech.2005.09.013

Nguyen, T. T. H., Li, S., Li, J., and Liang, T. (2013). Micro-distribution and fixation of a rosin-based micronized-copper preservative in poplar wood. Int. Biodeterior. Biodegrad. 83, 63-70. doi: 10.1016/j.ibiod.2013.02.017

Nicholas, D. D. (2018). Comparative field performance of oilborne pentachlorophenol versus the substituted isothiazolone DCOI as wood preservatives. Int. Wood Prod. J. 9, 171-175. doi: 10.1080/20426445.2018. 1548722

Niesler, M., and Surmacz-Górska, J. (2018). Pentachlorophenol degradation by activated sludge with phenol and glucose as growth substrates. Arch. Environ. Prot. 44:3. doi: 10.24425/123360

Obataya, E., Zeniya, N., and Endo-Ujiie, K. (2019). Effects of water-soluble extractives on the moisture sorption properties of spruce wood hygrothermally treated at 120C and different humidity levels. Wood. Mat. Sci. 16, 124-131. doi: $10.1080 / 17480272.2019 .1635642$

Onuorah, E. O. (2000). The wood preservative potentials of heartwood extracts of Milicia excelsa and Erythrophleum suaveolens. Bioresour. Technol. 75, 171-173.

Ozgenc, O., Hiziroglu, S., and Yildiz, U. C. (2012). Weathering properties of wood species treated with different coating applications. Bioresources 7, 4875-4888. doi: 10.15376/biores.7.4.4875-4888

Pandit, S. K., Tudu, B. K., Mishra, I. M., and Kumar, A. (2020). Development of stain resistant, superhydrophobic and self-cleaning coating on wood surface. Prog. Organ. Coat. 139:105453.

Pang, S. J., Oh, J. K., Hong, J. P., Lee, S. J., and Lee, J. J. (2017). Effect of incising on the long-term biodeterioration resistance of alkaline copper quaternary (ACQ) treated wood. Eur. J. Wood Prod. 75, 777-783. doi: 10.1007/s00107-016-1151

Panov, D., and Terziev, N. (2009). Study on some alkoxysilanes used for hydrophobation and protection of wood against decay. Int. Biodeterior. Biodegrad. 63, 456-461. doi: 10.1016/j.ibiod.2008.12.003

Pantano, D., Neubauer, N., Navratilova, J., Scifo, L., Civardi, C., Stone, V., et al. (2018). Transformations of nanoenabled copper formulations govern release, 
antifungal effectiveness, and sustainability throughout the wood protection lifecycle. Environ. Sci. Technol. 52, 1128-1138. doi: 10.1021/acs.est.7b04130

Parker, A. M. (2017). Investigation of Pyrolysis and Electrokinetics as Remediation Techniques for the Treatment of CCA-Treated Wood Waste. Thesis. Starkville, MS: Mississippi State University.

Passialis, C. N., and Voulgaridis, E. V. (1999). Water repellent efficiency of organic solvent extractives from Aleppo pine leaves and bark applied to wood. Holzforschung 53, 151-155. doi: 10.1515/hf.1999.025

Preston, A., Jin, L., Nicholas, D., Zahora, A., Walcheski, P., Archer, K., et al. (2008). Field stake tests with copper-based preservatives. Paper presented at the 39th Annual Meeting of the International Research Group on Wood P(IRG), Istanbul.

Railroad Ties Association [RTA] (2014). Basic Statistics. Railroad Ties Association. Available online at: http://www.rta.org/faqs-main (accessed August 30, 2021).

Rao, M. A., Simeone, G. D. R., Scelza, R., and Conte, P. (2017). Biochar based remediation of water and soil contaminated by phenanthrene and pentachlorophenol. Chemosphere 186, 193-201. doi: 10.1016/j.chemosphere. 2017.07.12

Rapp, A. (2001). "Review on heat treatment of wood," in Proceedings of COST E22 Special Seminar, Antibes.

Reinprecht, L. (2010). "Fungicides for wood protection. World viewpoint and evaluation/testing in Slovakia," in Fungicides, ed. O. Carisse (Rijeka: INTECH), 95-122.

Reinprecht, L. (2016). Wood Deterioration, Protection, and Maintenance. Hoboken, NJ: John Wiley \& Sons Ltd.

Richardson, H. W., and Hodge, R. L. (2016). Particulate Wood Preservative and Method for Producing Same. U.S. Patent 9,314,030. Griffin, GA: Koppers Performance Chemicals Inc.

Rickard, C., Singh, T., Singh, A., and Newman, R. (2009). Discovering Anti-Fungal Agents in New Zealand Native Plants for Use in Wood Protection. Stockholm: IRG on Wood Protection. Document no. IRG/WP 09-10692.

Roos, K. D., and Archer, K. J. (2004). Reactive Oil/Copper Preservative Systems for Wood Products. U.S. Patent 6,686,056. Chicago, IL: Archer Daniels Midland Co.

Rowell, R. M. (1975). Chemical modification of wood: advantages and disadvantages. Proc. Am. Wood Preserv. Assoc. 71, 1-10. doi: 10.3390/ molecules 24152782

Rowell, R. M. (1983). Chemical modification of wood: a review. Commonwealth For. Bureau 6, 363-382. doi: 10.1007/978-1-4684-5877-0_70

Rowell, R. M. (1991). "Chemical modification of wood," in Handbook on Wood and Cellulosic Materials, eds D. N.-S. Hon and N. Shiraishi (New York, NY: Marcel Dekker), 703-756.

Rowell, R. M. (1999). "Chemical modification of wood," in Proceedings of the International Workshop on Frontiers of Surface Modification and Characterization of Wood Fibers, eds P. Gatenholm and T. Chihani, Fiskebackskil, 31-47.

Rowell, R. M. (2016). Dimensional stability and fungal durability of acetylated wood. Drewno 59, 139-150.

Rowell, R. M., Ibach, R. E., McSweeny, J., and Nilsson, T. (2009). Understanding decay resistance, dimensional stability and strength changes in heat treated and acetylated wood. Wood Mater. Sci. Eng. 4, 14-22. doi: 10.1080/ 17480270903261339

Sablik, P., Giagli, K., Paril, P., Baar, J., and Rademacher, P. (2016). Impact of extractive chemical compounds from durable wood species on fungal decay after impregnation of nondurable wood species. Eur. J. Wood Prod. 74, 231-236. doi: 10.1007/s00107-015-0984-z

Sandberg, D., Haller, P., and Navi, P. (2013). Thermo-hydro and thermohydro-mechanical wood processing: an opportunity for future environmentally friendly wood products. Wood Mater Sci. Eng. 8, 64-88. doi: 10.1080/17480272. 2012.751935

Sandberg, D., and Kutnar, A. (2016). Thermally modified timber: recent developments in Europe and North America. Wood Fiber Sci. 48, 28-39.

Sandberg, D., Kutnar, A., and Mantanis, G. (2017). Wood modification technologies - a review. iForest 10, 895-908. doi: 10.3832/ifor2380-010

Schauwecker, C., Clauson, M., Konkler, M. J., Sinha, A., and Morrell, J. J. (2020). Properties of aging pentachlorophenol-treated douglas-fir crossarms. For. Prod. J. 70, 364-369. doi: 10.13073/FPJ-D-20-00025

Schmitt, S., Zhang, J., Shields, S., and Schultz, T. (2014). "Copper-based wood preservative systems used for residential applications in North America and Europe," in Deterioration and Protection of Sustainable Biomaterials, eds T. P.
Schultz, B. Goodell, and D. D. Nicholas (Washington, DC: American Chemical Society), 217-225. doi: 10.1021/bk-2014-1158.ch012

Schultz, T. P., and Nicholas, D. D. (2004). "Solid wood processing | protection of wood against biodeterioration," in Encyclopedia of Forest Sciences, ed. J. Burley (Amsterdam: Elsevier), 1274-1282. doi: 10.1016/B0-12-145160-7/00048-X

Schultz, T. P., and Nicholas, D. D. (2007). "Totally organic wood preservative for exterior residential applications," in Wood Protection, ed. H. M. Barnes (Madison: Forest Products Society), 289-294.

Schultz, T. P., Nicholas, D. D., and Kelly, S. (2006). A Nonleachable Waterborne Composition of Resin Acids and Wood Preserving Organic Biocides. U. S. Patent 11/689,278. Mississippi State, MS: Mississippi State University and U.S. Department of Energy's National Renewable Energy Lab.

Schultz, T. P., Nicholas, D. D., and Preston, A. F. (2014). "Wood protection trends in North America," in Deterioration and Protection of Sustainable Biomaterials, eds T. P. Schultz, B. Goodell, and D. D. Nicholas (Blacksburg, VA: American Chemical Society), 351-361. doi: 10.1021/bk-2014-1158. ch021

Scown, D. K., Creffield, J. M., and Hart, R. S. (2009). Laboratory Study on the Termiticidal Efficacy of Eremophilone Oil. Stockholm: The International Research Group on Wood Protection. Document no. IRG/WP 00-30497.

Sen, S., Tascioglu, C., and Tirak, K. (2009). Fixation, leachibiliy and decay resistance of wood treated with some commercial extracts and wood preservative salts. Int. Biodeterior. Biodegrad. 63, 135-141. doi: 10.1016/j.ibiod.2008.07.007

Shiny, K. S., and Sundararaj, R. (2021). Biologically synthesised copper oxide and zinc oxide nanoparticle formulation as an environmentally friendly wood protectant for the management of wood borer, Lyctus africanus. Maderas Cienc. Tecnol. 23, 1-12. doi: 10.4067/s0718-221x2021000100447

Sierra-Alvarez, R. (2009). Removal of copper, chromium and arsenic from preservative-treated wood by chemical extraction-fungal bioleaching. Waste Manag. 29, 1885-1891. doi: 10.1016/j.wasman.2008.12.015

Simpanen, S., Mäkelä, R., Mikola, J., Silvennoinen, H., and Romantschuk, M. (2016). Bioremediation of creosote contaminated soil in both laboratory and field scale: investigating the ability of methyl- $\beta$-cyclodextrin to enhance biostimulation. Int. Biodeterior. Biodegrad. 106, 117-126. doi: 10.1016/j.ibiod. 2015.10.013

Singh, T., and Chittenden, C. (2008a). Antifungal Activity of Essential Oils Against Common Wood Degrading/Decaying Fungi. Stockholm: IRG on Wood Protection. Document no. IRG/WP 08-30465.

Singh, T., and Chittenden, C. (2008b). In vitro antifungal activity of chilli extracts in combination with Lactobacillus casei against common sapstain fungi. Int. Biodeterior. Biodegrad. 62, 364-367. doi: 10.1016/j.ibiod.2007.10.009

Singh, T., Chittenden, C., Singh, A. P., and Franich, R. (2008a). Chitosan as a potential wood preservative. Wood Process. Newslett. 46:448.

Singh, T., Vesentini, D., Singh, A. P., and Daniel, G. (2008b). Effect of chitosan on physiological, morphological and ultrastructural characteristics of wood degrading fungi. Int. Biodeterior. Biodegrad. 62, 116-124. doi: 10.1016/j.ibiod. 2007.09.006

Singh, T., and Page, D. (2016). CCA treated wood, will it last 100 years?. Paper Presented at the 7th International Research Group on Wood Protection (IRG) Annual Meeting, Lisbon.

Singh, T., and Page, D. (2020). Evaluation of selected accelerated above-ground durability testing methods for wood after ten years exposure. Forests 11:559. doi: 10.3390/f11050559

Singh, T., and Singh, A. P. (2012). A review on natural products as wood protectant. Wood Sci Technol. 46, 851-870. doi: 10.1007/s00226-011-0448-5

Sirmah, P., Dumarcay, S., Masson, E., and Gerardin, P. (2009a). Unusual amount of (-)-mesquitol from the heartwood of Prosopis juliflora. Nat. Prod. Res. 23, 183-189. doi: 10.1080/14786410801940968

Sirmah, P., Iaych, K., Poaty, B., Dumarcay, S., and Gerardin, P. (2009b). Effect of Extractives on Durability of Prosopis juliflora Heartwood. Stockholm: The International Research Group on Wood Protection. Document no. IRG/WP 09-30518.

Sivrikaya, H., Can, A., Tümen, I., and Aydemir, D. (2017). Weathering performance of wood treated with copper azole and water repellents. Wood Res. 62:2017.

Slahor, J. J., Hassler, C. C., and Dawson-Andoh, B. (2001). The durability of yellowpoplar and American beech treated with chromated copper arsenate. For. Prod. J. 51:62. 
Slahor, J. J., Hassler, C. C., and Gardner, D. J. (1997). Preservative treatment evaluation with CCA and ACQ-B of four appalachian wood species for use in timber transportation structures. For. Prod. J. 47:33.

Smith, S. T. (2019). 2018 railroad tie survey. J. Transp. Technol. 9:276. doi: 10.4236/ jtts. 2019.93017

Srinivasan, U., Ung, T., Taylor, A., and Cooper, P. A. (1999). Natural durability and waterborne preservative treatability of tamarack. For. Prod. J. 49:82.

Stirling, R., Uzunovic, A., and Morris, P. I. (2011). Control of black stain fungi with biocides in semitransparent wood coatings. For. Prod. J. 61, 359-364. doi: 10.13073/0015-7473-61.5.359

Stirling, R., and Wong, D. (2019). "Performance of field cut preservatives above-ground and in ground contact exposures," in Proceedings of the 50th International Research Group on Wood Protection Annual Meeting, Quebec City.

Stratton, J., and Stokes, C. (2016). Multidisciplinary remediation: an analysis of chlorinated metabolites in groundwater contaminated by pentachlorophenol following 15 years of Air/biosparging, phytoremediation, and in-situ chemical oxidation protocols. Paper Presented at 45th Mississippi Water Resources Conference, Jackson, MS.

Sudell, G., Selvakumar, A., and Wolf, G. (1992). Contaminants and Remedial Options at Wood-Preserving Sites. Washington, DC: U.S. Environmental Protection Agency.

Tascioglu, C., Tufan, M., Yalcin, M., and Sen, S. (2016). Determination of biological performance, dimensional stability, mechanical and thermal properties of wood-plastic composites produced from recycled chromated copper arsenatetreated wood. J. Thermoplast. Compos. Mater. 29, 1461-1479. doi: 10.1177/ 0892705714565704

Tascioglu, C., Yalcin, M., Sen, S., and Akcay, C. (2013). Antifungal properties of some plant extracts used as wood preservatives. Int. Biodeter. Biodegrad. 85, 23-28. doi: 10.1016/j.ibiod.2013.06.004

Tascioglu, C., Yalcin, M., Troya, T., and Sivrikaya, H. (2012). Termiticidal properties of some wood and bark extracts used as wood preservatives. Bioresources 7, 2960-2969. doi: 10.15376/biores.7.3.2960-2969

Taylor, A. M., Gartner, B. L., Morrell, J. J., and Tsunoda, K. (2006). Effects of heartwood extractive fractions of Thuja plicata and Chamaecyparis nootkatensis on wood degradation by termites or fungi. J. Wood Sci. 52, 147-153. doi: 10.1007/s10086-005-0743-6

Teacǎ, C.-A., Roşu, L., Marlicǎ, E., Roşu, D., Rusu, T., Mustaţǎ, F., et al. (2018). Investigation of wood properties after treatment by impregnation with natural vegetable oils. Paper Presented at the 12th European Symposium on Thermal Analysis and Calorimetry (ESTAC12), Braşov.

Temiz, A., Alfredsen, G., Eikenes, M., and Terziev, N. (2008). Decay resistance of wood treated with boric acid and tall oil derivates. Bioresour. Technol. 99, 2102-2106. doi: 10.1016/j.biortech.2007.08.052

Temiz, A., Alfredsen, G., Yildiz, U. C., Gezer, E. D., Kose, G., Akbas, S., et al. (2014). Leaching and decay resistance of alder and pine wood treated with copper-based wood preservatives. Maderas Cienc. Tecnol. 16, 63-76. doi: 10. 4067/S0718-221X2014005000006

Temiz, A., Nilsson, T., Y $ı l d l z$, U. C., Gezer, E. D., and Y $\imath l d l z$, S. (2004). "The efficacy of wood preservative treatments in laboratory soil-bed test," in Proceedings of the IRG 35th Annual Meeting, Ljubljana.

Thevenon, M. F., Pizzi, A., and Haluk, J. P. (1997). Non-toxic albumin and soja protein borates as ground-contact wood preservatives. Eur. J. Wood Wood Prod. 55, 293-296. doi: 10.1007/s001070050231

Thevenon, M. F., Pizzi, A., and Haluk, J. P. (1998). Protein borates as non-toxic, long-term, wide-spectrum, ground-contact wood preservatives. Holzforschung 52, 241-248. doi: 10.1515/hfsg.1998.52.3.241/html

Tjeerdsma, B. F., and Militz, H. (2005). Chemical changes in hydrothermal treated wood. FTIR analysis of combined hydrothermal and dry heat-treated wood. Holz. Roh Werkstoff 63, 102-111.

Torr, K. M., Chittenden, C., Franich, R. A., and Kreber, B. (2005). Advances in understanding bioactivity of chitosan and chitosan oligomers against selected wood-inhabiting fungi. Holzforschung 59, 559-567. doi: 10.1515/HF.20 05.092

Torr, K. M., Singh, A. P., and Franich, R. A. (2006). Improving stiffness of lignocellulosics through cell wall modification with chitosan melamine copolymers. N.Z. J. For. Sci. 36, 87-98.
Townsend, T., Tolaymat, T., Solo-Gabriele, H., Dubey, B., Stook, K., and Wadanambi, L. (2004). Leaching of CCA-treated wood: implications for waste disposal. J. Hazard. Mater. 114, 75-91. doi: 10.1016/j.jhazmat.2004. 06.025

Treu, A., Larnøy, E., and Militz, H. (2009). "Leaching of new environmental friendly wood protection agents," in Proceedings of the 5th meeting of the NordicBaltic Network in Wood Material Science and Engineering (WSE), Copenhagen.

Trine, L. S. D., Davis, E. L., Roper, C., Truong, L., Tanguay, R. L., and Simonich, S. L. M. (2019). Formation of PAH derivatives and increased developmental toxicity during steam enhanced extraction remediation of creosote contaminated superfund soil. Environ. Sci. Technol. 53, 4460-4469. doi: 10.1021/acs.est.8b07231

United States Environmental Protection Agency [U.S. EPA] (2008). Reregistration Eligibility Decision for Pentachlorophenol. EPA 739-R-08-008. September 25, 2008. 103. Available online at: https://www3.epa.gov/pesticides/chem_search/ reg_actions/reregistration/red_PC-025004_25-Sep-08.pdf (accessed August 20, 2021).

United States Environmental Protection Agency [U.S. EPA] (2021). Non-prous Secondary Material (NHSM) Regulations 40 CFR Part 241. US EPA. Available online at: https://www.epa.gov/sites/default/files/2021-05/documents/nhsm_ guide_5_26_2021.pdf (accessed August 25, 2021).

Uysal, S. (2016). Potential for Using Boron Compounds with Differing Water Solubilities in Pastes for Remedial Treatment of Utility Poles. Master's thesis. Corvallis, OR: Oregon State University.

Uysal, S., Cappellazzi, J., and Morrell, J. (2018). Potential for using borate mixtures as groundline preservative pastes. J. Boron 3, 71-78. doi: 10.30728/boron. 328592

Verly Lopes, D. J., Barnes, H. M., and dos Santos Bobadilha, G. (2020). Influence of heat treatment and tannin impregnation on boron depletion and wood durability. Forests 11:201. doi: 10.3390/f11020201

Vidal, J. M., Evangelista, W. V., Silva, J. D. C., and Jankowsky, I. P. (2015). Preservação de madeiras no Brasil: histórico, cenário atual e tendências. Cienc. For. 25, 257-271. doi: 10.1590/1980-509820152505257

Vidor, F. L., Pires, M., Dedavid, B. A., Montani, P. D., and Gabiatti, A. (2009). Inspection of wooden poles in electrical power distribution networks in southern Brazil. EEE Trans. Power Deliv. 25, 479-484. doi: 10.1109/TPWRD. 2009.2034913

Virkutyte, J., Velizarova, E., Ribeiro, A. B., and Sillanpää, M. (2005). Copper and chromium electrodialytic migration in CCA-treated timber waste. Water Air Soil Pollut. 160, 27-39. doi: 10.1007/s11270-005-3427-3.pdf

Voda, K., Boh, B., Vrtacnik, M., and Pohleven, M. (2003). Effect of the antifungal activity of oxygenated aromatic essential oil compounds on the white-rot Trametes versicolor and the brown-rot Coniophora puteana. Int. Biodeterior. Biodegrad. 51, 51-59. doi: 10.1016/s0964-8305(02)00075-6

Wang, S. Y., Chen, P. F., and Chang, S. T. (2005). Antifungal activities of essential oils and their constituents from indigenous cinnamon (Cinnamomum osmophloeum) leaves against wood decay fungi. Bioresour. Technol. 96, 813818. doi: 10.1016/j.biortech.2004.07.010

Wang, Y.-J., Lee, C. C., Chang, W. C., Liou, H. B., and Ho, Y. S. (2001). Oxidative stress and liver toxicity in rats and human hepatoma cell line induced by pentachlorophenol and its major metabolite tetrachlorohydroquinone. Toxicol. Lett. 122, 157-169. doi: 10.1016/s0378-4274(01)00361-7

Warburton, P. S., Mason, L., and Hughes, A. S. (2017). Wood Preservative Formulations Comprising Isothiazolones Which Provide Protection against Surface Staining. U.S. Patent Application 15/354,585. Castleford: Arch Timber Protection Ltd.

Webb, D., Fox, R., and Pfeiffer, R. (2009). Creosote posts-final inspection of the 1958 cooperative test after 50 years of exposure as a ground contact preservative. Paper Presented at 105th Annual Meeting of the American Wood Protection Association, Santo Antonio, TX.

Weigenand, O., Humar, M., Daniel, G., Militz, H., and Mai, C. (2008). Decay resistance of wood treated with amino- silicone compounds. Holzforschung 62, 112-118.

Welzbacher, C. R., Rapp, A. O., Haller, P., and Wehsener, J. (2005). "Biological and mechanical properties of densified and thermally modified Norway spruce," in Proceedings of the Second European Conference on Wood Modification, Göttingen. 
Williams, L. H. (1996). Borate wood-protection compounds: a review of research and commercial use. APT Bull. J. Preser. Tech. 27, 46-51. doi: 10.2307/1504564

Williams, R. S. (1999). "Finishing of wood," in Wood Handbook: Wood as an Engineering Material, ed. R. J. Ross (Madison, WI: U.S. Department of Agriculture).

Xu, T., Xin, M., Li, M., Huang, H., and Zhou, S. (2010). Synthesis, characteristic and antibacterial activity of N,N,N-trimethyl chitosan and its carboxymethyl derivatives. Carbohyd. Polym. 81, 931-936. doi: 10.1016/j.carbpol.2010.04.008

Yan, L., and Morrell, J. J. (2019). Kinetic color analysis for assessing the effects of borate and glycerol on thermal modification of wood. Wood Sci. Technol. 53, 263-274. doi: 10.1007/s00226-018-1072-4

Yang, D. Q. (2009). Potential utilization of plant and fungal extracts for wood protection. For. Prod. J. 59, 97-103.

Yang, D. Q., Wang, X. M., Shen, J., and Wan, H. (2004). Antifungal properties of barks of various wood species. For. Prod. J. 54, 37-39.

Yang, V. W., and Clausen, C. A. (2007). Antifungal effect of essential oils on Southern yellow pine. Int. Biodeterior. Biodegrad. 59, 302-306.

Yildiz, S. (2007). Retention and penetration evaluation of some softwood species treated with copper azole. Build. Environ. 42, 2305-2310. doi: 10.1016/j. buildenv.2006.11.015

Yin, Y., Berglund, L., and Salmen, L. (2011). Effect of steam treatment on the properties of wood cell walls. Biomacromology 12, 194-202. doi: 10.1021/ bm101144m

Yu, L., Cai, J., Li, H., Lu, F., Qin, D., and Fei, B. (2017). Effects of boric acid and/or borax treatments on the fire resistance of bamboo filament. Bioresources 12, 5296-5307. doi: 10.15376/BIORES.12.3.5296-5307

Yuksel, M., Baysal, E., Toker, H., and Simsek, H. (2014). Combustion characteristics of Oriental beech wood impregnated with commonly used borates. Wood Res. 59, 39-49.
Zaidon, A., Moy, C. S., Sajap, A. S., and Paridah, M. T. (2003). Resistance of CCA and boron-treated rubberwood composites against termites, Coptotermes curvignathus Holmgren, Pertanika. J. Sci. Technol. 11, 65-72.

Zelinka, S. L., and Rammer, D. R. (2009). Corrosion rates of fasteners in treated wood exposed to $100 \%$ relative humidity. J. Mater. Civ. Eng. 21, 758-763.

Zhang, J., Zhang, W., and Leach, R. M. (2012). Micronized Wood Preservative Formulations Comprising Boron Compounds. U.S. Patent 8,168,304. Syracuse, NY: Osmose Inc.

Zhang, J., Leach, R. M., and Griffin, P. (2014). Micronized Wood Preservative Formulations. U.S. Patent 8,778,407. Buffalo, NY: Osmose, Inc.

Conflict of Interest: The authors declare that the research was conducted in the absence of any commercial or financial relationships that could be construed as a potential conflict of interest.

The handling editor declared a past collaboration with one of the author GS.

Publisher's Note: All claims expressed in this article are solely those of the authors and do not necessarily represent those of their affiliated organizations, or those of the publisher, the editors and the reviewers. Any product that may be evaluated in this article, or claim that may be made by its manufacturer, is not guaranteed or endorsed by the publisher.

Copyright (C) 2022 Khademibami and Bobadilha. This is an open-access article distributed under the terms of the Creative Commons Attribution License (CC BY). The use, distribution or reproduction in other forums is permitted, provided the original author(s) and the copyright owner(s) are credited and that the original publication in this journal is cited, in accordance with accepted academic practice. No use, distribution or reproduction is permitted which does not comply with these terms. 